\title{
اختصاصات المكمة الدستورية الأردنية بين الواقع النظري والتطبيق العملي
}

\author{
shel \\ أ.د / محمد وليد العبادى \\ أستاذ القانون الدستورى - كليت القانون \\ جامعتّآل البيت - المفرق -الأردن
}


سنذهب مع ما يقول به الفقه الاستوري إلى أن جمود الاستور وعلوه أو سموه

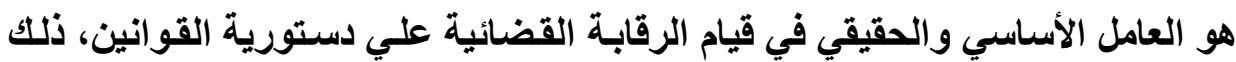

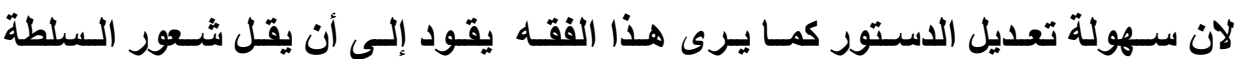

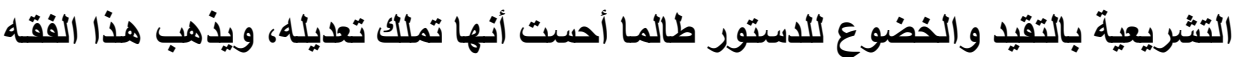

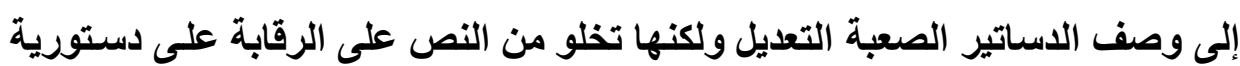
القو انين بالاساتير شبه الجامدة. هذا ولمسا كـان دستور به 190 عندنا دستورا جامسا ويطلو على مـا عداه مـن

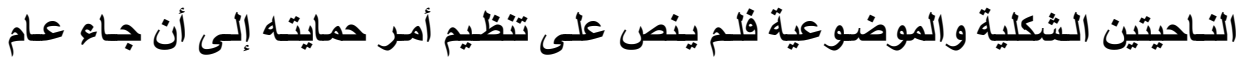

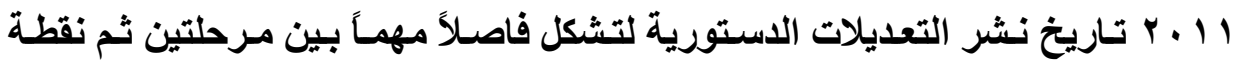
تحول كبيرة عندما أمرت المادة (هـ) من الدستور أن تنشأ بقانون محكمة دستورية يكون مقرها في العاصمة وتعتبر هيئة قضائية مستقلة قائمة بذاتها. وتتفاوت اختصاصات المحاكم الدستورية إذ تتسع في بعض الدول، وتضيق في

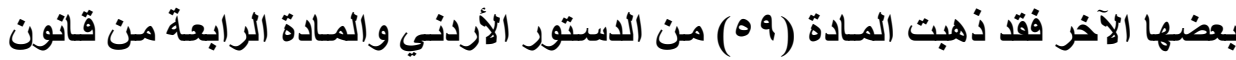

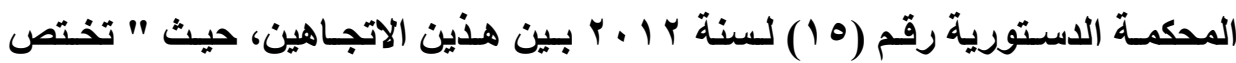

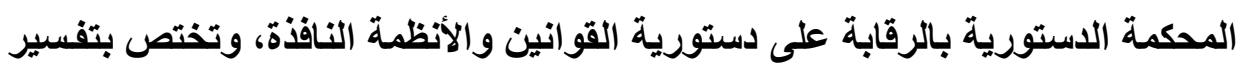
نصوص الاستور (') و وعليه وحتى نستطيع بيان ذلك فإنتا سنقسم موضوع بحثنا إلى فصلين: ـ الفصل الأول : يتعلق بطرق الرقابة على دستورية القوانين والأنظمة النافذة. - الفصل الثاني : ويتعلق بتفسير نصوص الدستور.

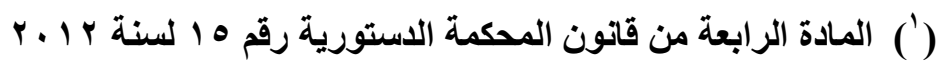


أ. د / محمد وليد العبادى

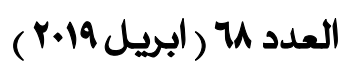




\section{الفصل الأول}

\section{طرق الرقابة على دستورية القوانين والأنظمة النافذة}

نصت المـادة (9 ه) من الدستور على أن تختص المحكمـة الاستورية بالرقابـة

على دستورية القوانين والأنظمـة النافذة، وجـاءت المـادة الرابعة من قـانون المحكمـة

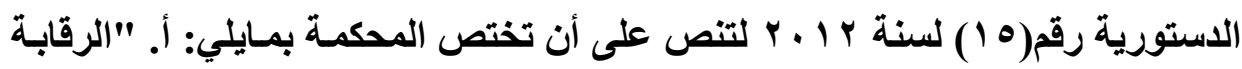
على دستورية القوانين والأنظمة النافذة".

وعليه فالواضح من هذين النصين أن اختصاص المحكمة الدستورية يشمل كل القوانين ولكن هل يشمل كل الأنظمة؟ مل ملت

بالنسبة للقوانين فالمقصود مـا يصدر عن السلطة التشريعية طبقاً للإجراعات الخاصة في المادتين ( اب ، ب 9) من الدستور الأردني النافذ المفعول. وكذلك الرجوع إلسى النظـام الـاخلي لمجلس النـواب والنظــام الـاخلـي لمجلس الأعيـان، والقـرارات التفسيرية للـيوان الخـاص المكملة والمتممسة للقـانون والتـي تنص على ذلك المـادة

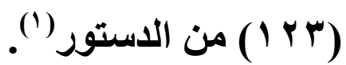

(1) تنص المادة (آم) على " الملك يصدق على القوانين ويصدرها ويأمر بوضع الأنظمة اللازمة

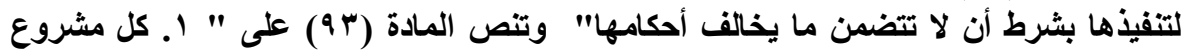

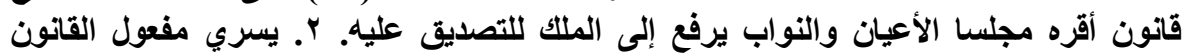

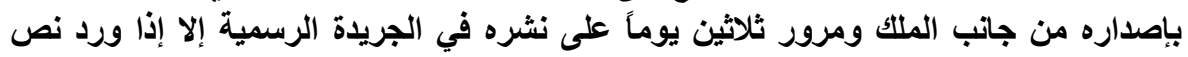

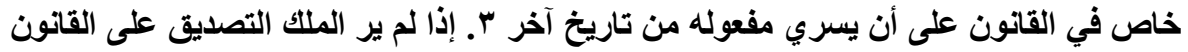

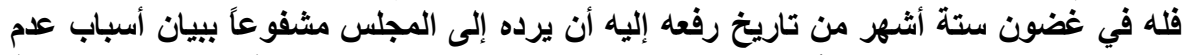

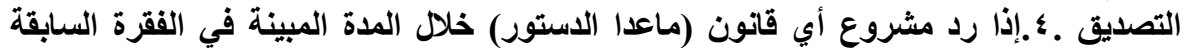

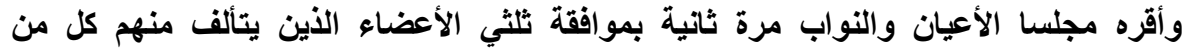
$=$ 
وكذلك القوانين المؤقتة في المـادة (ع 9)( ) والمعاهدات والاتفاقيات التي يوافق

عليها مجلس الأمة حسب ما تنص عليه المادة" بr" من الاستور (†).

المجلسين وجب عندئذ إصداره، وفي حالة عدم إعادة القانون مصدقاً في المدة المعينة في الفقرة

الثالثة من هذه المادة يعتبر نافذ المفعول وبحكم المصدق.

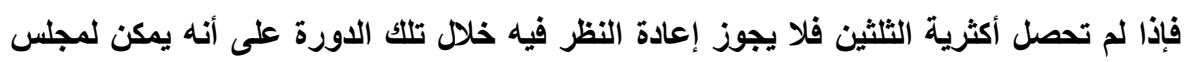

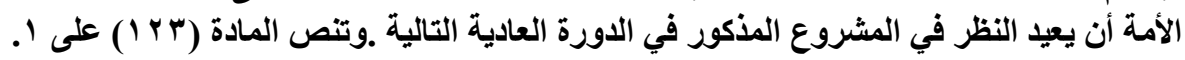

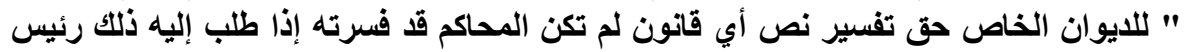

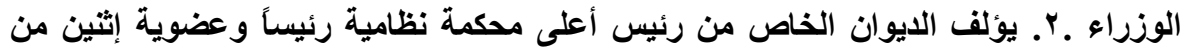

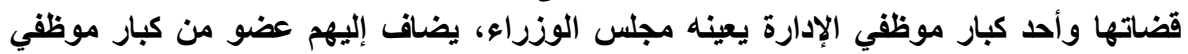

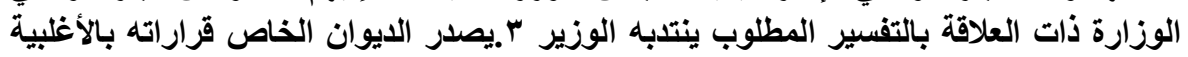

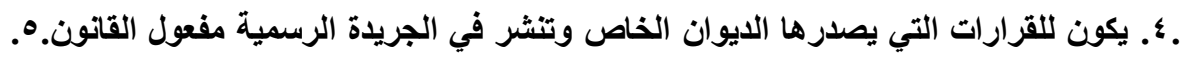

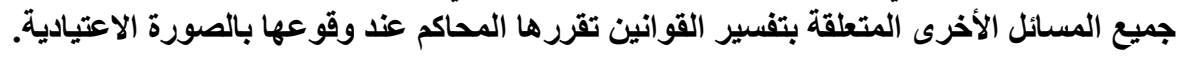

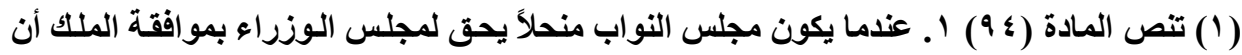
يضع قوانين مؤقتة لمواجهة الأمور الآتي بيانها:

$$
\begin{aligned}
& \text { 1) الكوارث العامة. }
\end{aligned}
$$

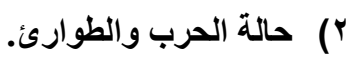

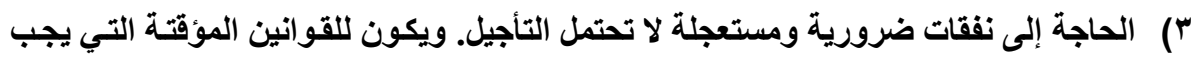

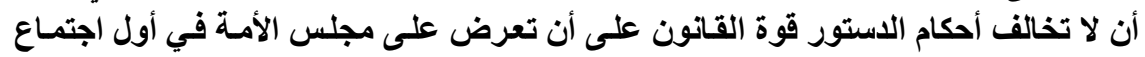

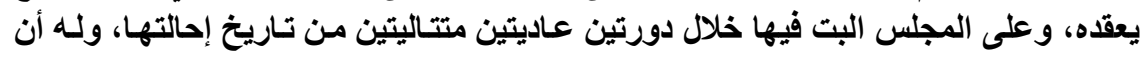

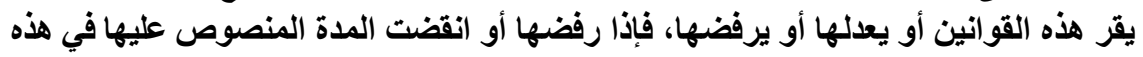

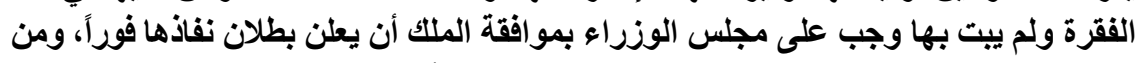

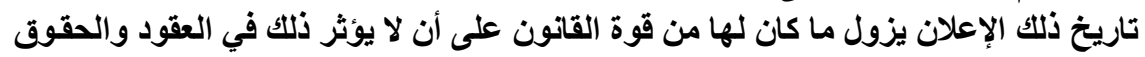

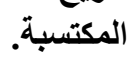

r. يسري مفعول القو انين المؤقتة بالصورة التي يسري فيها مفعول القوانين بمقتضى حكم

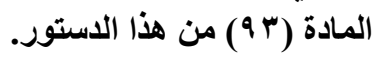

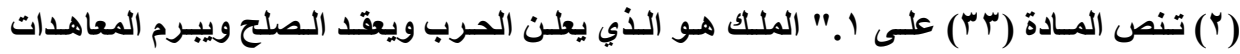

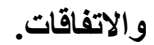

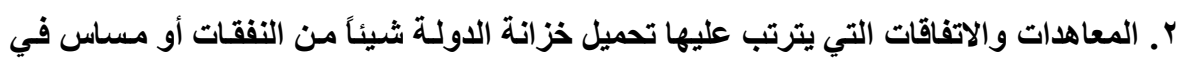

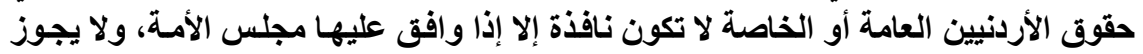

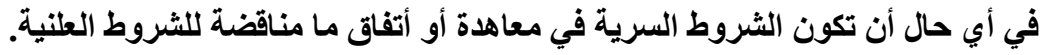




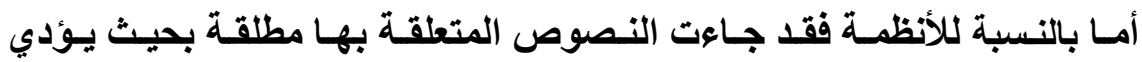
تفسيرها اللفظي إلى جعل اختصاص المحكمة الاستورية برقابـة الاستورية شـاملاً لكل للأنظمة، وهنا يؤكد الفقه الاستوري بأن الرقابة على دستورية الأنظمة يجب أن تقتصر على تلك التي تتمتع بالصفة التشريعية والقوة الملزمة للتشريع، ولا تمتـد إلى الأنظمـة التنفيذية ما دامت هذه الأنظمة تعتبر في نظر القضاء الإداري قرارات إدارية لا تخضع لرقابة المشروعية حول مدة انطباقها أو عدم انطباقها مـع القانون ولا تخضع لرقابـة (الاستورية. وعليه ولما كاتت الأنظمة عندنا تنفيذية وفقاً لنص المادة (با") من

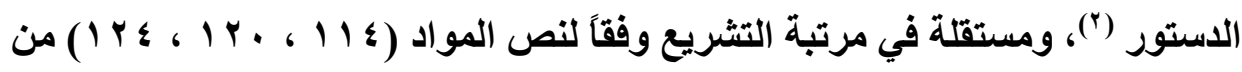

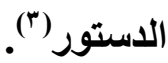

(1) راجع في هذا: الاكتور رمزي الثاعر : النظرية العامـة للقانون الاستوري ـالطبعة الخامسة ـ

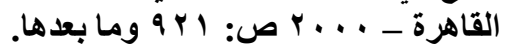

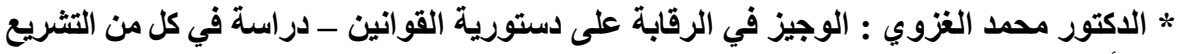

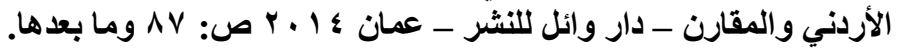

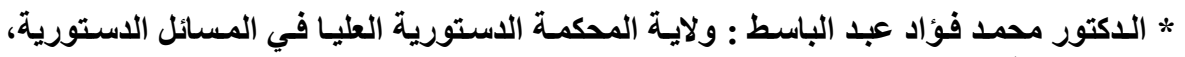

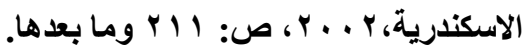

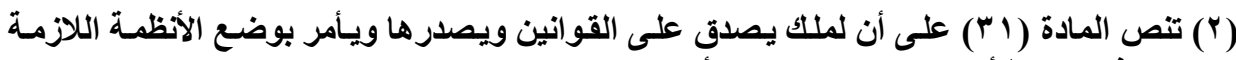

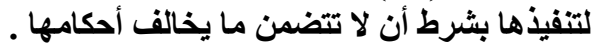

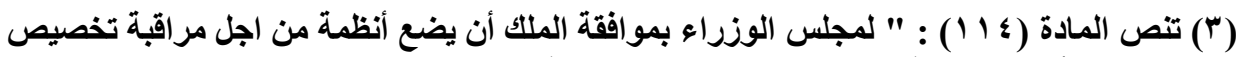

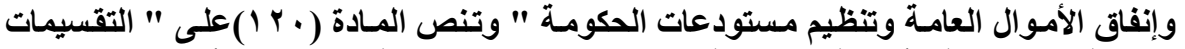

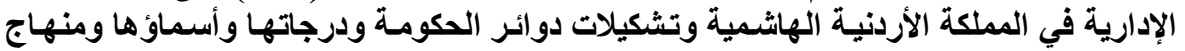

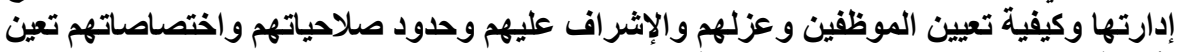

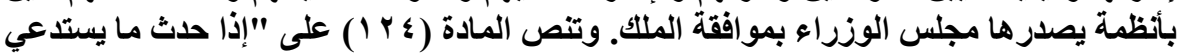

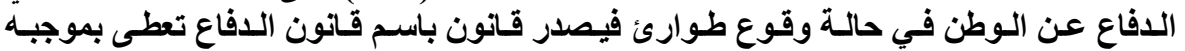

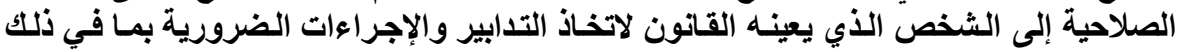

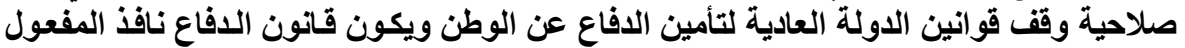

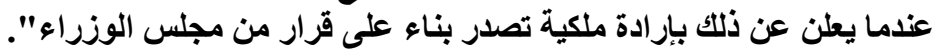


وإذا ما رجعنا إلى الفقه فإنه يقصر رقابة المحكمة الاستورية على الأنظمة التي

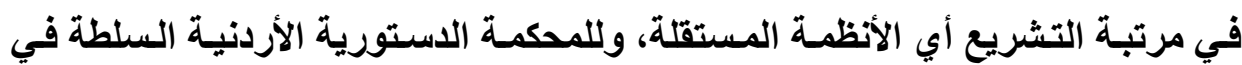
الذهاب إلى هذا الخيـار ولا تتمسك بـإلاق النص وتفسيره اللفظي. ونجد أن عضو الفو المحكمة الاستورية الدكتور محمد الغزوي يخـالف مـا ذهبت إليه المحكمة الدستورية

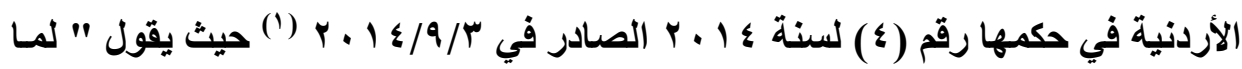
قد يبدو أن المحكمة الدستورية وهي تفصل في مدى دستورية قانونها تكون في موقع الخصم والحكم، فالخصم الحقيقي يبقى هو مصدر القـانون يستوي في ذلكت قـانون

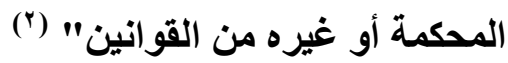

\section{وحول اختصاص المكمة على دستورية القوانين والأنظمة النافذة.}

فيكون اختصاصها طبقاً لنص المادة( • ؟) من الاستور والمادتان 9/أو 11 من

قانون المحكمة الاستورية سالف الأكر عن طريق الطعن المباشر والدفع الفرعي. (")

( (1) يراجع هذا الحكم والمخالفة والتعليق عليه في المبحث الثاني من هذا البحث.

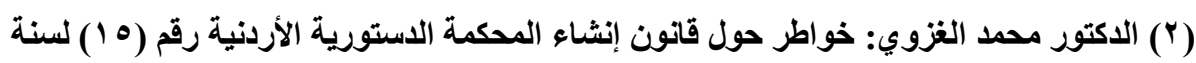

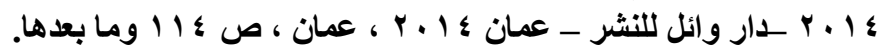

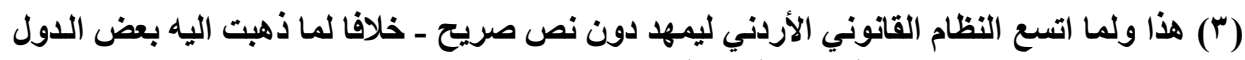

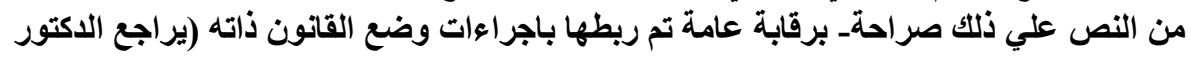

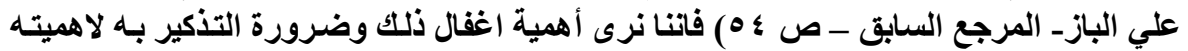

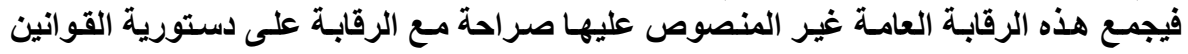

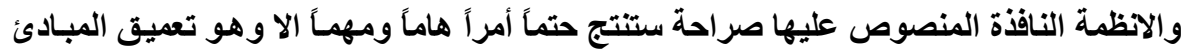

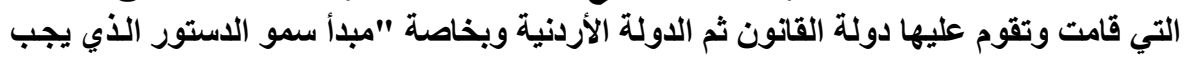

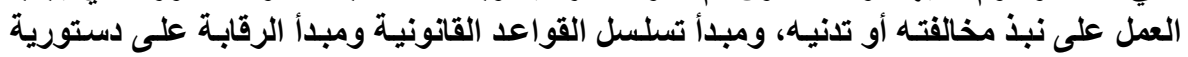

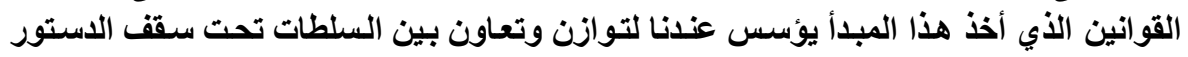

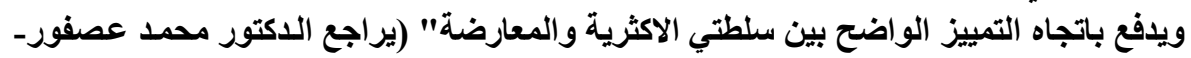

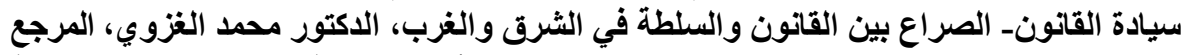

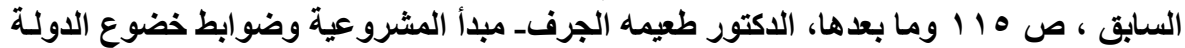

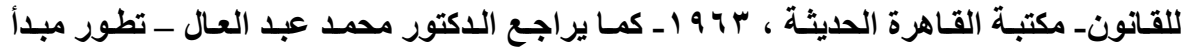
$=$ 
وقبل الانتقال إلى دراسة هاتين الطريقتين فلا بـ من وقفة لنبين أهمية هذا الطريق الذي سلكه النظام القانوني الأردني في مجال الرقابة على دستورية القوانين

ففي اعتماده لطريقة الطعن المباشر حقى مزايا كثيرة تناولها الفقه الاستوري.

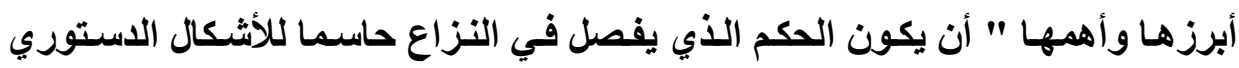

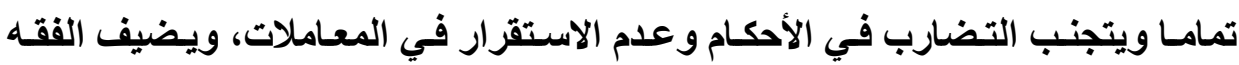
وهناك ميزة ثانية تنص على تثكيل المحكمة بطريقة تراعى فيها الاعتبارات السياسية. هذا وفي اعتماد الأردن لطريق الدفع الفرعي (') يكون قد خفف آليا هذا الطعن الذي وجه لطريق الطعن المباشر وكذلك المخاطر التي يؤدي إليها هذا الطعن من انه النه

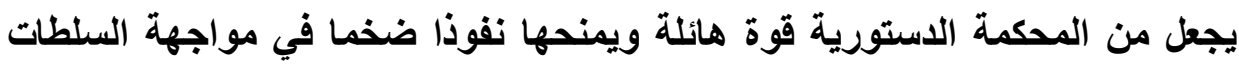

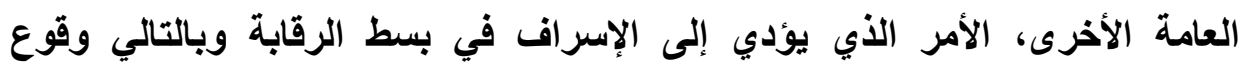

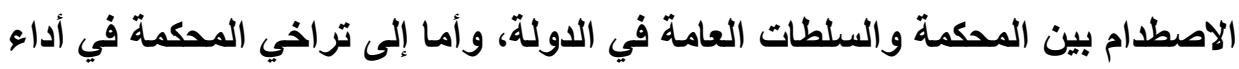

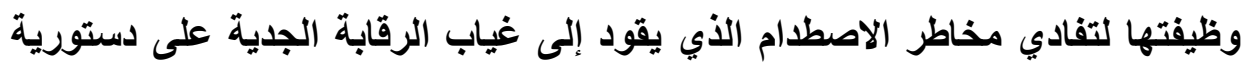

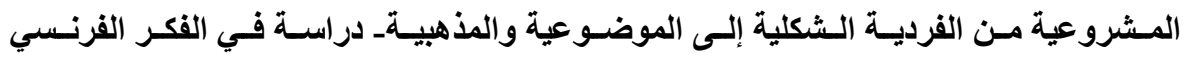

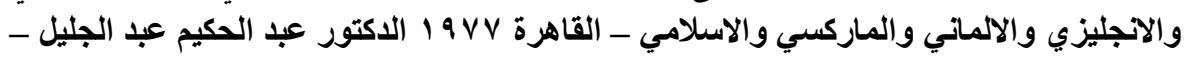

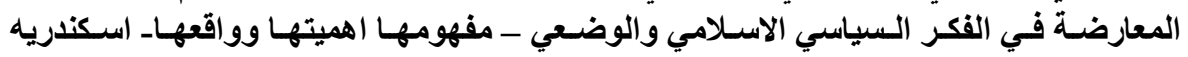

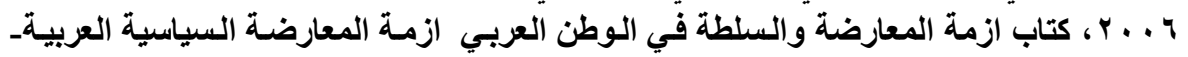

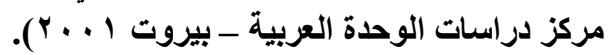

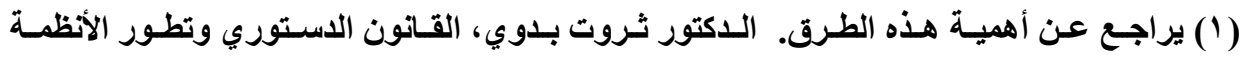

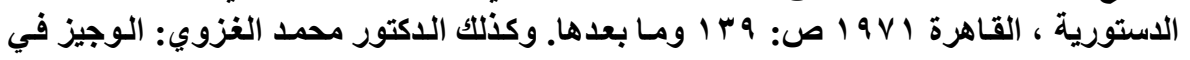

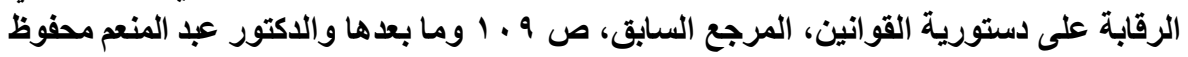

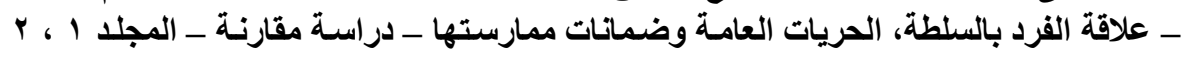

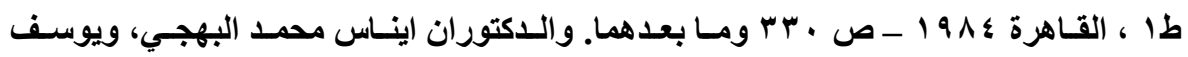

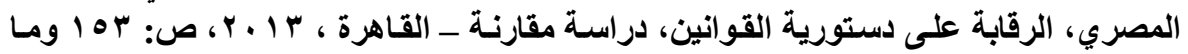


القوانين. هذا وعلاوة على ما تقدم فان اعتماد طريق الدفع الفرعي يمتاز انه اقل عنفا وأكثر مرونة وبالتالي لا يؤدي إلى الصدام مع السلطات العامة في الدولة ولا يهديد

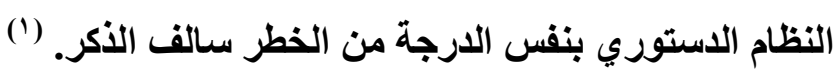
أما ما يؤخذ عليها فهو مأخذ عملي لا قانوني من السهل تجاوزه ويخاصة عندما

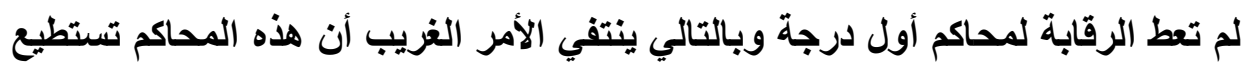

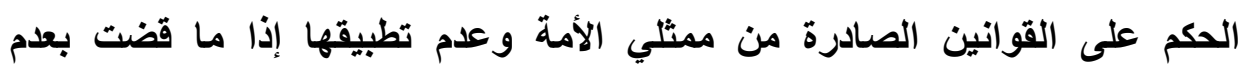
دستوريتها ولا محل لأي اعتراضات قانونية في حال وجود نص في الاستئور يقرن

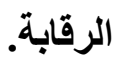
و انطلاقًاً مما سبق فإنتا سنتتاول هاتين الطريقتين في مبحثين المبحث الأول : يتعلق بطريقة الطعن المباشر. المبحث الثاني: ويتعلق بطريقة الدفع بعدم دستورية القوانين والأنظم.

• الدكتور محمد الغزوي: الوجيز في الرقابة على دستورية القوانين، المرجع السابق، ص ـ11. 


\section{المبحث الأول \\ طريقة الطعن المباشر}

المقصود بالطعن المباشر بعلم الاستورية هو إثارة المسألة الاستورية من خلال دعوى أصلية. ولا تتصل هذه الدعوى كما تقول المحكمة الدستورية العليا

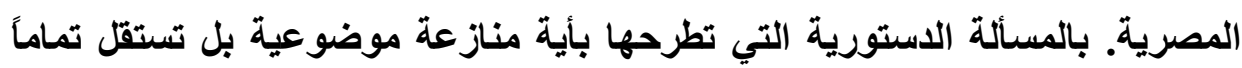

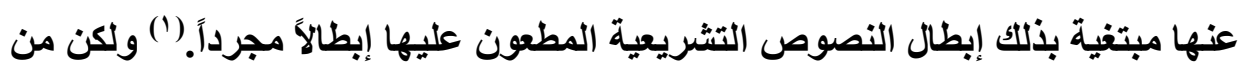
هي الهيئة التي يجوز لها استعمال هذا الطريق. بمراجعة الأنظمة الاستورية نجد (†):

1. هـاك مـن النظم مـن تقصر هذا الحقى على بعض الهيئات وهي مجلس الأمسة

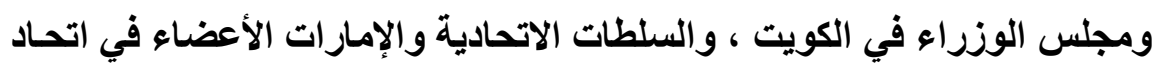

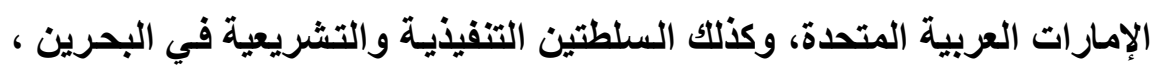
ورئيس الجمهورية والأحزاب السياسية ومجلس القضاء الأعلى في تركيا. r. و وهناك من النظم من يعطي الحق للأفراد ولكن بطريق غير مباثر كالاستور الايطالي والألماني.

r. ـ وهناك من النظم من يعطي الحق للأفراد كما هو الحال في سويسرا و اسبانيا.

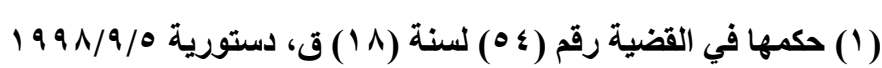

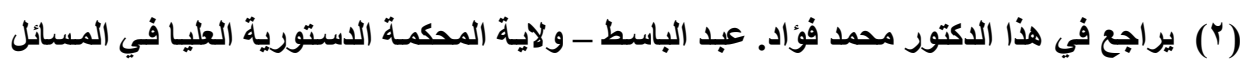

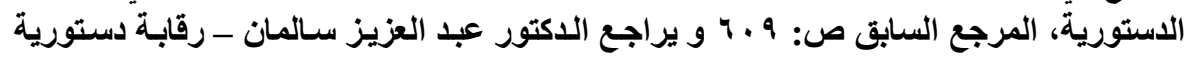

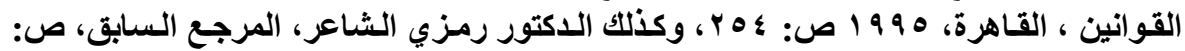

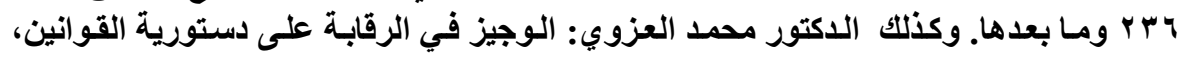

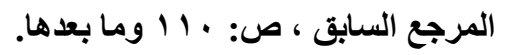


أما بالنسبة لطريقة الطعن المباشر لاى المحكمـة الاستورية الأردنيـة فيتم من

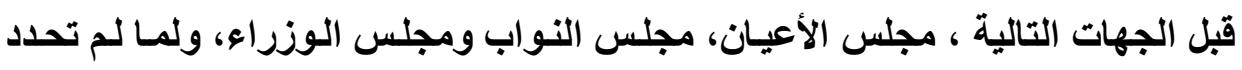

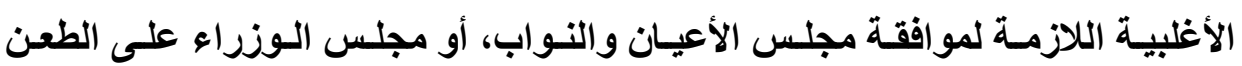

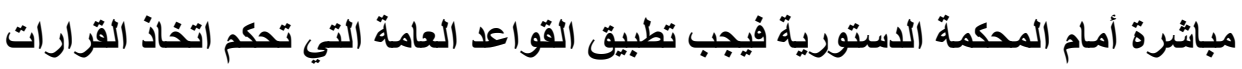
في هذه المجالس على أكثرية أصوات الأعضاء الحاضرين.

وبمراجعة أحكام المحكمة الاستورية لم يجري أي طعن على مدى أربع سنوات

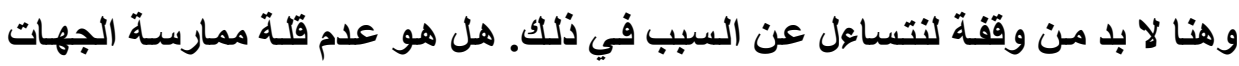

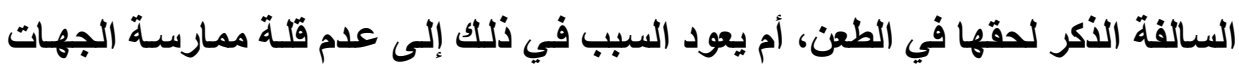

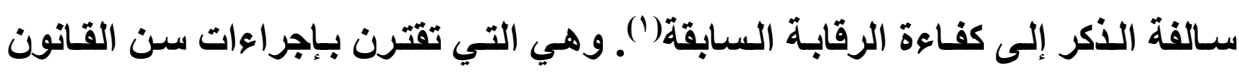
ذاته؟ أم غير ذلك؟ التهر التح

ونحن نعتقد أن عدم ممارسة الحق بالطعن المباشر من كل من مجلس الوزراء

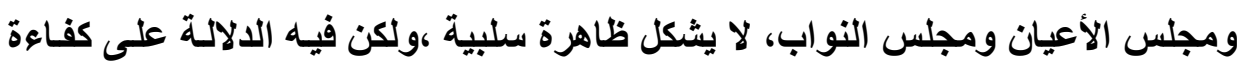

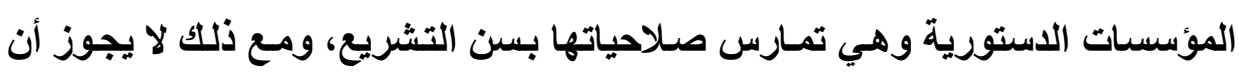

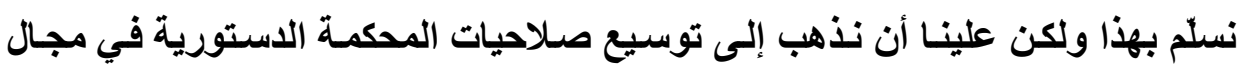
الطعن المباشر.وذلك بإعطاء الحق لمؤسسـات المجتمع المـدني. النقابـات والأحزاب السياسية وغير ها.

كمـا نقترح أن نذهب إلى الاستفادة من تجربـة المحكمة الدستورية في ألمانيا

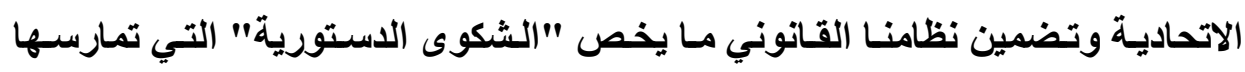
المحكمة الاستورية الألمانية حيث تفصل في المنازعات التي تمس الحقوق الأنس الأساسية

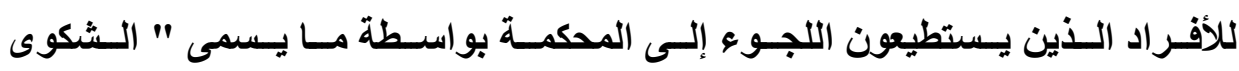

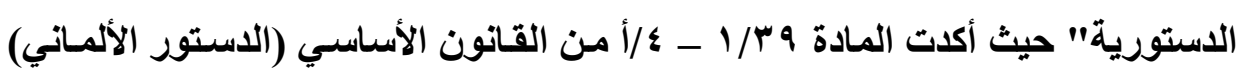

(1) د. محمد العزوي، الوجيز في الرقابة على دستورية القوانين - المرجع السابق - هامش رقمب ص: 4 ـ 1 وما بعدها. 
بشأن الثكاوي الدستورية التي يمكن لكل شخص أن يرفعها إلى المحكمة بلدعوى أن السلطات العامة قد انتهكت احد حقوقه الأساسية.

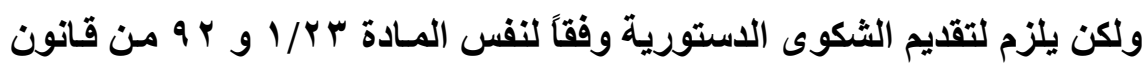

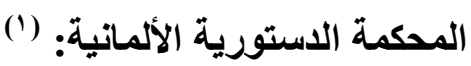

ا. ـ أن يكون الضرر قد وقع عليه شخصياً. r. أن يكون الضرر قد وقع عليه في الزمن الحاضر. rا أن يكون الفعل قد انتهك بشكل مباثر احد حقوقه التي يكفلها له الاستور.

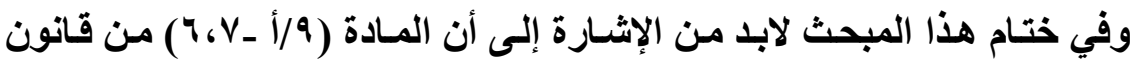

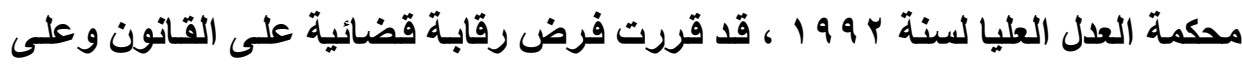
النظام. فما هو مجال كل من المحكمة الاستورية ومحكمة العلا العليا:

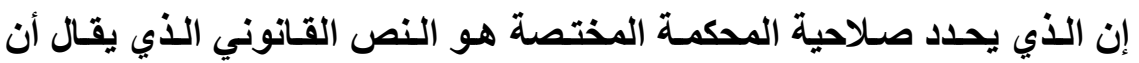

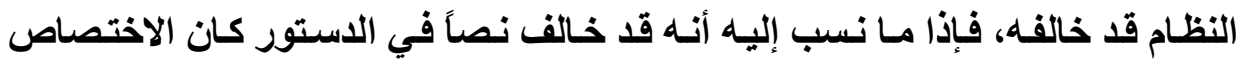

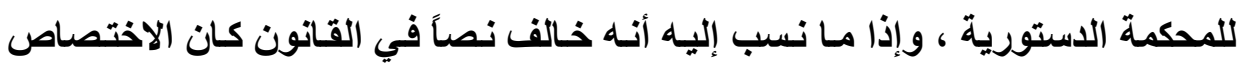

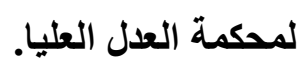
أما إذا ما خالف النظام القانوني الذي صدر مستنداً إليه وخالف في الوقت ذاته الاستور فإن الاختصاص يكون هنا للمحكمة الدستورية لأن حماية الاستور تأتي قبل

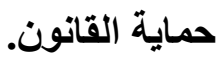

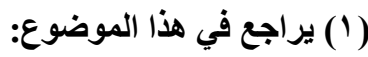

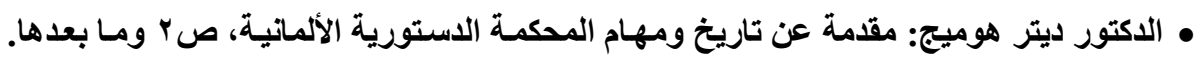

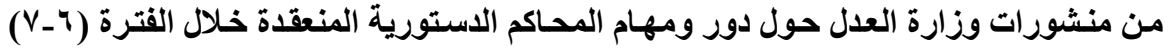

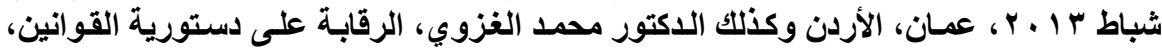
المرجع السابق، ص • • ؛ وما بعدها. 
أ. د / محمد وليد العبادى

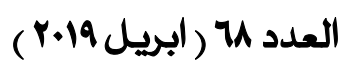




\section{المبحث الثاني \\ طريقة الدفع بعدم دستورية القوانين والأنظمة}

لقد أخذت بهذه الطريقة دول كثيرة وفي مقدمتها الولايـات المتحدة الأمريكية

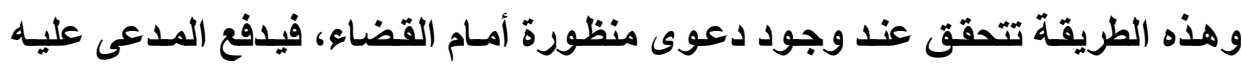

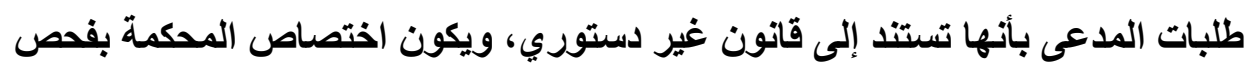

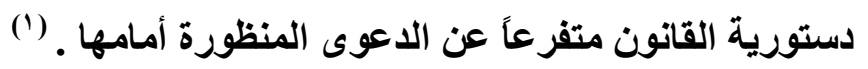

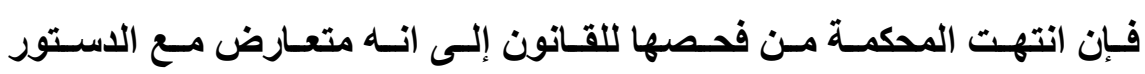

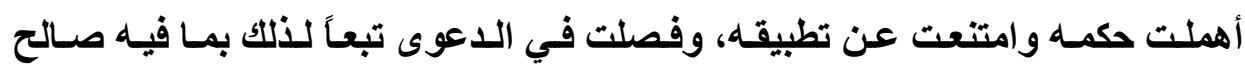

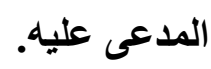

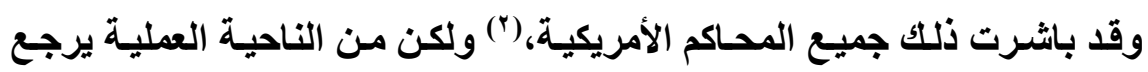

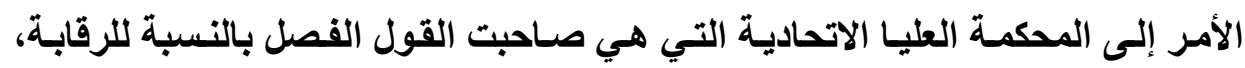
ويعود السبب في ذلك إلى :

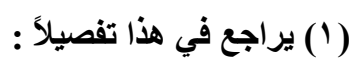

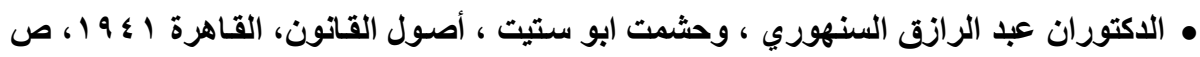

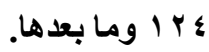

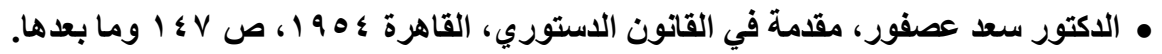

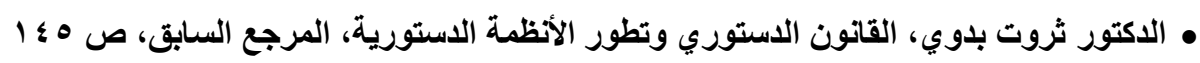
وما بعدها.

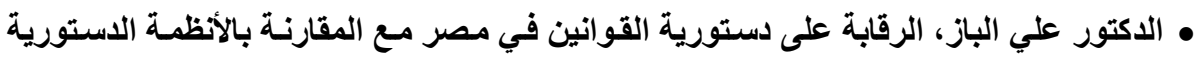

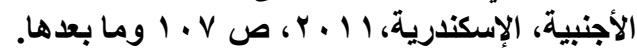

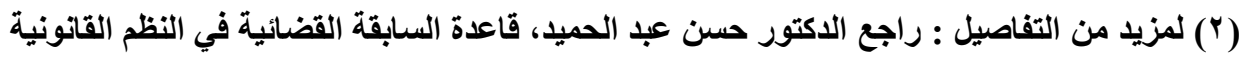

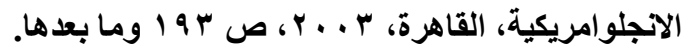


التزام المحاكم الأمريكية بنظام السوابق القضائية التي تفرض على القاضي أن يطبق بشروط معينة القواعد القانونية التي استتبطها قضاه آخرون في قضايا سـابقة مماثلة هذا من ناحية، ومن ناحية أخرى أن سلطة المحكمة العليا الاتحادية(') في إلغاء

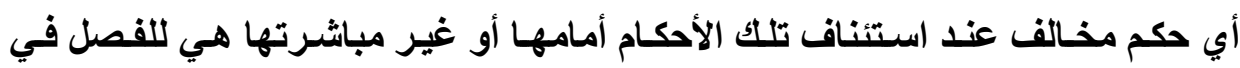
الدعوى عن طريق قرارات التصدي التي تأمر بموجبها المحاكم إرسال أوراق وملفات التاتيات القضايا لها لتفصل فيها هذا بالنسبة للمحاكم الأمريكية.

أما إذا كان النظام الدستوري يأخذ بمبلأ مركزية الرقابة فتوقف الدحكمة الفصل

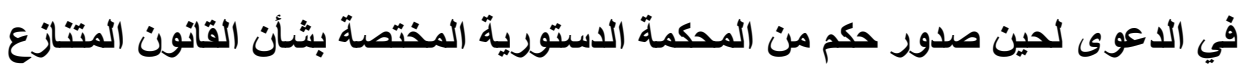

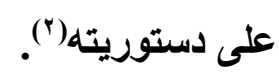

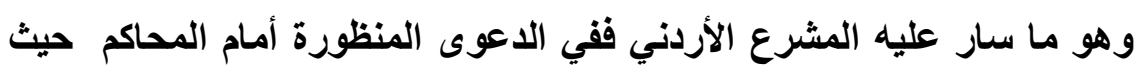

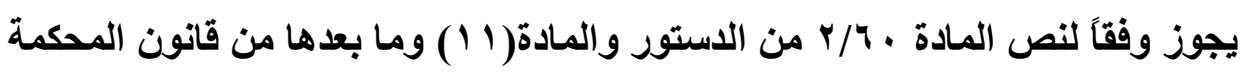

(1) الاكتور هشام عبد الفتاح، رقابة دستورية القوانين دراسة مقارنة بين أمريكا ومصر، القاهرة

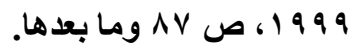

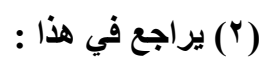

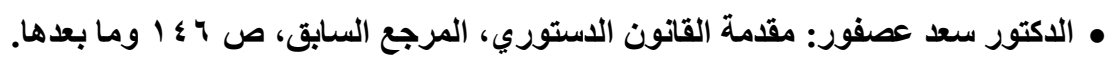

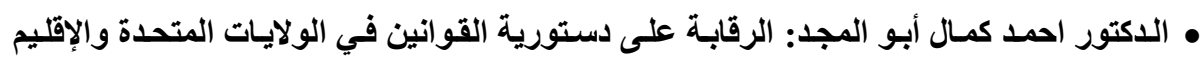

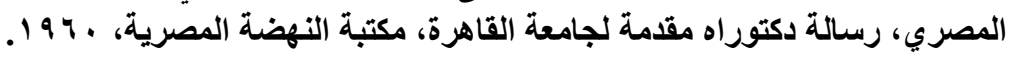

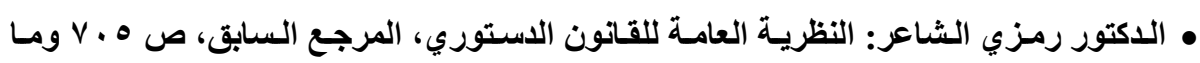
بعدها. • الاكتور محمد فؤاد عبد الباسط : ولاية المحكمة الاستورية، المرجع السابق، ص ץ ؟ ومـا

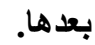
• الدكتور محمد الغزوي: تطور الرقابة على دستورية القوانين والأنظمة في ظل الاستور الأردني

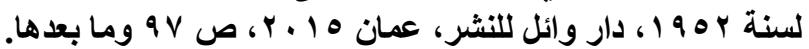

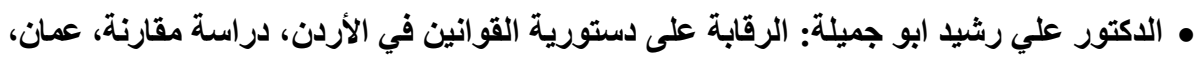

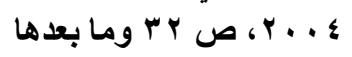


الاستورية لأي من أطراف الدعوى إثارة الدفع بعدم الدستورية وعلى المحكمة إن

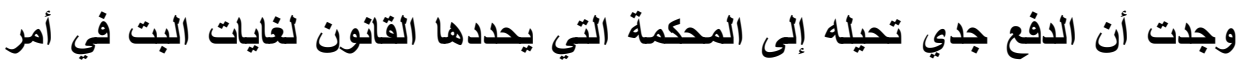
إحالته إلى المحكمة الاستورية. وعليه وفي ضوء ما تضمنته النصوص السابقة ووفق الإجراءات والأوضاع التي نصت عليها:-

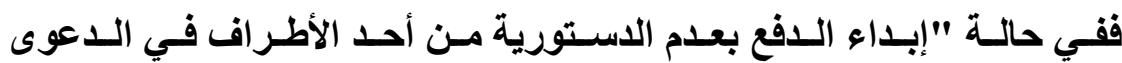
الموضوعية، يتعين أن يقام الدفع بعدم الدستورية أمام المحكمة الناظرة للاعوى وذلك التك

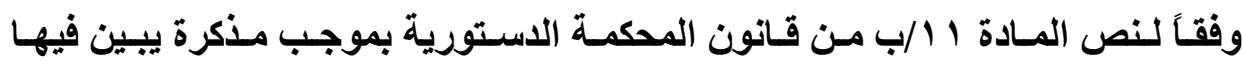
الطاعن اسم القانون أو النظام الذي أثير الدفع بعدم دستوريته ورقمه ونطاق الدفع

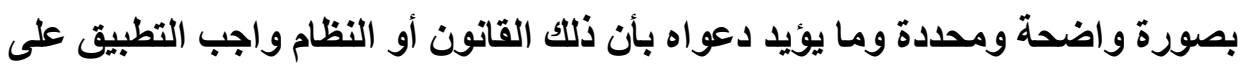
موضوع الاعوى ووجه مخالفته للاستور.

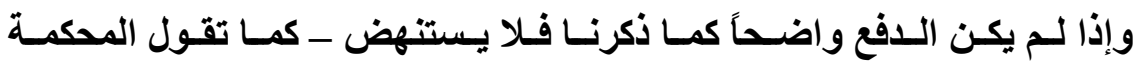

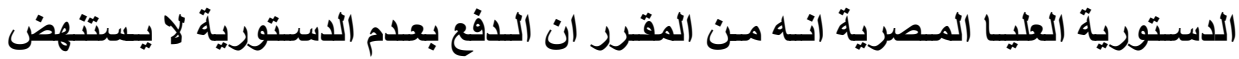

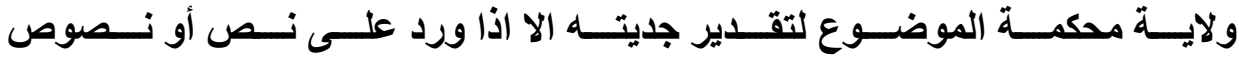
بذاتها عينها المدعي وحدادها باعتبار ها نطاقًاً لدفعه متضمناً تحديد أبعاده كي تجيل محكمة الموضوع بصرها في النصوص المطعون عليها لتقار جدية المطاعن الموجهة

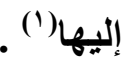

وتضيف النصوص أيضاً أن الدفع حتى يكون منتجاً يجب أن يكون جدياً، حسب

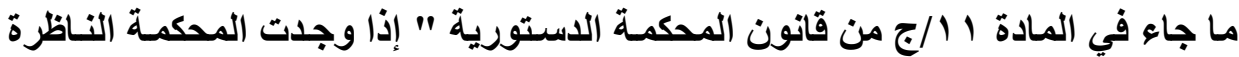

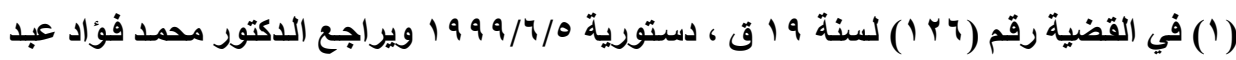
الباسط - المرجع السابق ـ صم: 1 ـ 1 ؛ وما بعدها. 


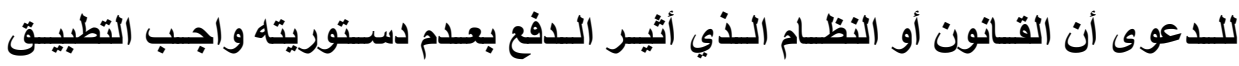

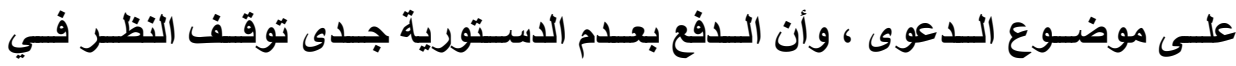

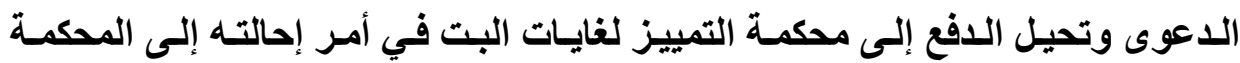

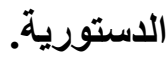

هذا ويشترط بالجدية كما بينت ذلك المحكمة الدستورية العليا المصرية "أن يكون القانون أو النظام المطعون في دستوريته متصل بموضوع النزائ كماع باع وأن يكون هناك

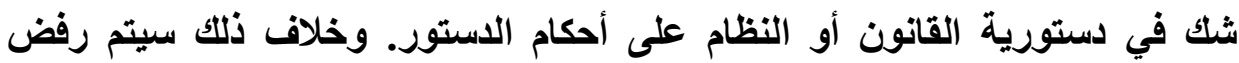

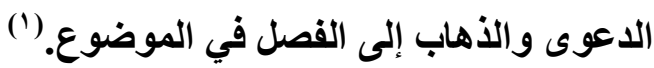
و إذا ثبتت الجدية وتوافرت عناصرها السالفة الذكر فإن سلطة قاضي الموضوع تجاه الافع (وقت النظر في الاعوى) وإحالته إلى محكمة التمييز التي تنعقد بهيئة من

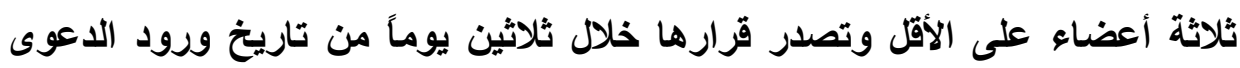

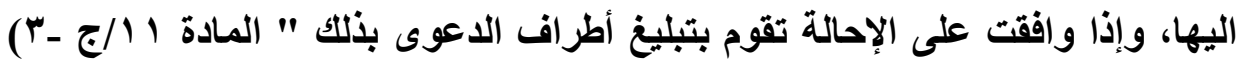
ووفقاً لنص المادة ///جــا من قانون المحكمة الاستورية فإن قرار المحكمة الناظرة للاعوى. بعدم الإحالة يكون قابل للطعن. هذا وإذا أثير الدفع بعدم الدستورية أمسام محكمة التمييز أو المحكمة الإداريـة

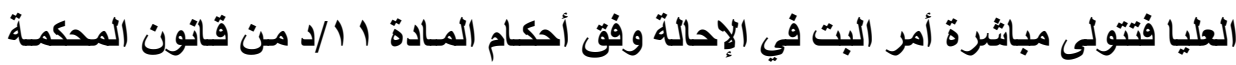

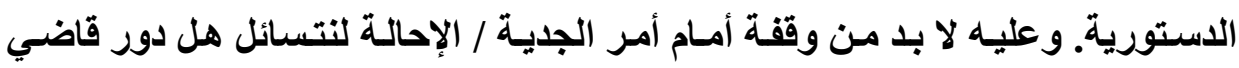

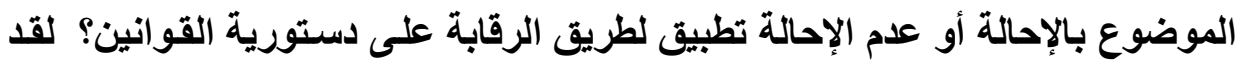

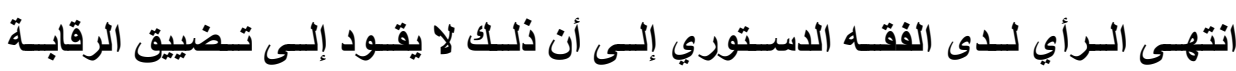

(1) الدكتور رمزي الشاعر ، رقابـة دستورية القوانين - دراسـة مقارنـة ، القـاهرة / ؛ . . r ـ ص: r^A 
وطريق الرقابـة بل هو تنظيم مقيد لها يهـدف إلى منـع الكيدية ومنـع إثـغال العدالـة

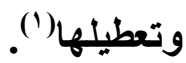

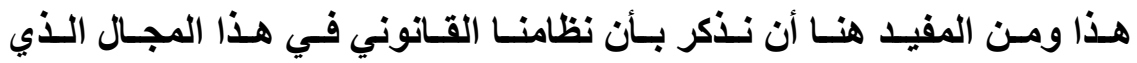

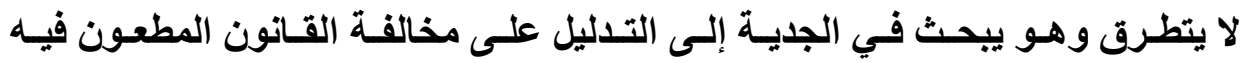

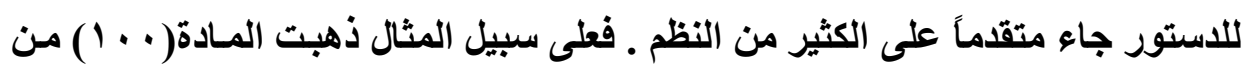
الاستور الألماني إلى الطلب من القاضي الذي يثار أمامه الدفع بعدم الاستورية أن يقدر

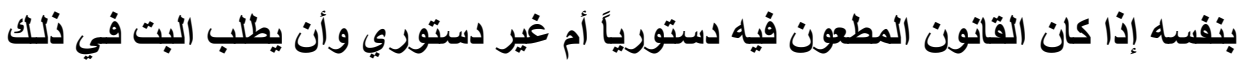
من المحكمة الاستورية. هذا وأصدرت المحكمة الاستورية الأردنية حتى الآن (r أ) حكماً.

هذا وفي ختام الحديث عن كل من الطريقتين سـالفتي الذكر، تصدر المحكمة الاستورية أحكامها باسم الملك وتكون أحكامها نهائية وملزمة لجميع السلطات والكافة

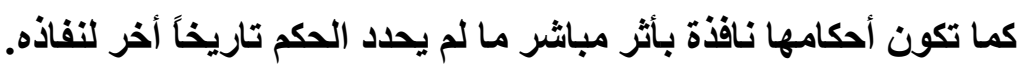
وتنشر أحكام المحكمة الدستورية في الجريدة الرسمية خلال خمسة عشر يومـاً

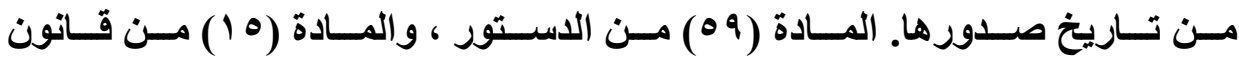

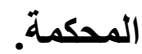

(1) الاكتور علي الباز - الرقابة على دستورية القوانين في مصر مـع المقارنـة بالأظظمة الدستورية

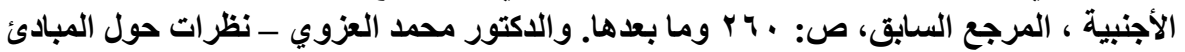

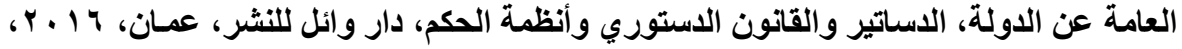

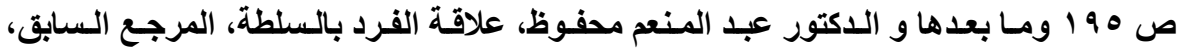


أ. د ا محمد وليد العبادى

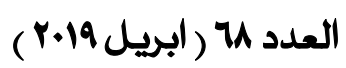

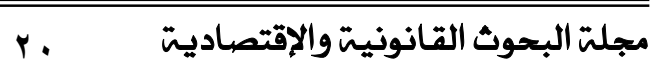




\section{الفصل الثاني}

\section{إسناد تفسير نصوص الدستور إلى المكمة الدستورية}

يقصد بالتفسير تحديد معنى القاعدة القانونية وبيـان مداها. وعلى العكس ممـا

يراه البعض فإن التفسير ينصرف إلى كافة القواعد اللستورية أياً كان مصدرها، الا أن أهميته تبدو بالنسبة للقواعد الدستورية المكتوبة، حيث تصاغ القواعد القانونية في

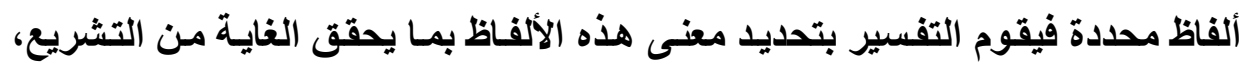

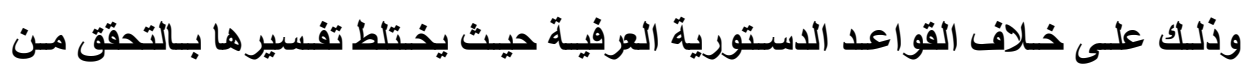

وهذا ويعتبر القضاء من المصادر التفسيرية الهامة للقانون الدستوري في البلاد التي تأخذ بالرقابة القضائية على دستورية القوانين، حيث تتولى المحكمة التي يوكل إليها أمر تفسير نصوص الاستور. وهنا يجب تحديد الجهة التي يلجأ إليها في حالة الاختلاف حول تفسير النص الاستوري الوارد في الاستور.

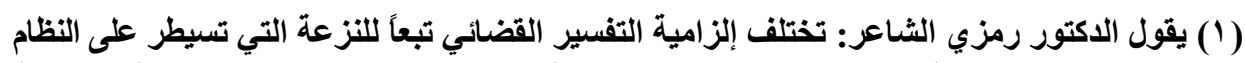

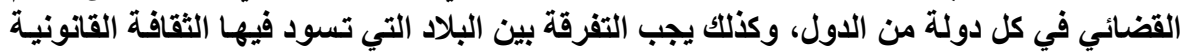

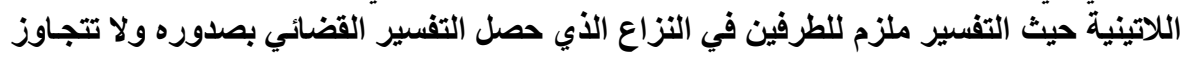

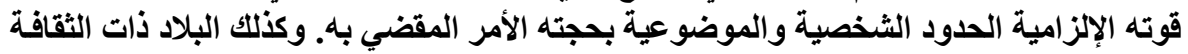
القانونية الانجلوسكونية التي تأخذ بنظام السو ابتى القضائية. 
ومسن هنـا يسأتي دور المحكمـة الاسـتورية بالبحـث عن مـدى تطـابق القاعدة

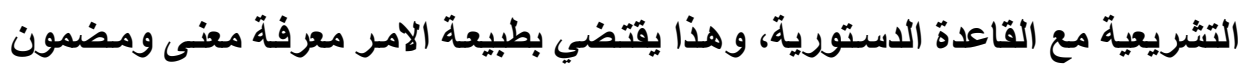
كل من النص الاستوري والنص التشريعي. (1)

و إذا ما رجعنا إلى الاستور الأردني لسنة بهو 19 وتعليلاته، نجد ان الفقرة

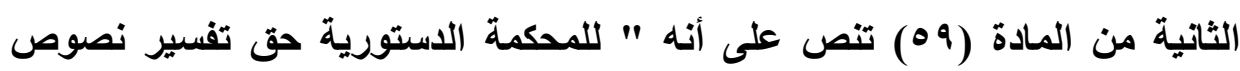

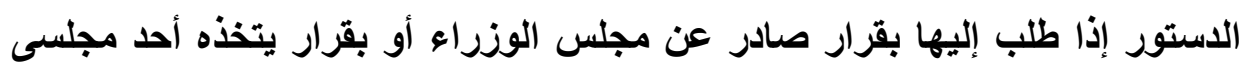
الأمة بالأغلبية المطلقة ويكون قرارها نافذ المفعول بعد نشره في الجريدة الرسمية". و إنطلاقًاً مما سبق سنتناول هذا الفصل من خلال مبحثين: المبحث الأول: يتطلق بممارسة المحكمة الاستورية للتفسير. المبحث الثاني: يتعلق بالأحكام والقرارات الصادرة عن المحكمة الاستورية . 


\section{المبحث الأول \\ همارسة المكمة الدستورية للتفسير}

في البداية يجب أن نفرق بين مرحلتين، المرحلة الأولى قبل إنثاء المحكمة الاستورية، والمرحلة الثانية بعد إنثاء المحكمة الاستورية حيث أسندت هذه المهن المهمة

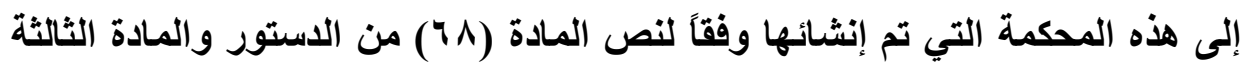

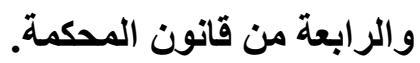
وسوف نتناول هاتين المرحلتين بشيء من التفصيل من خلال مطلبين :

\section{المطلب الأول: قبل إنشاء المكمة الدستورية}

ذهب المشرع الاستوري قبل إنشاء المحكمة الاستورية والتعديلات التي أدخلت

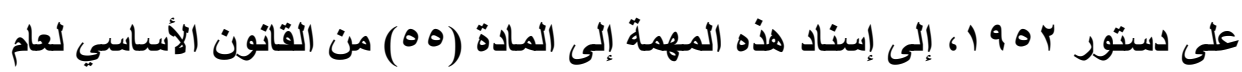

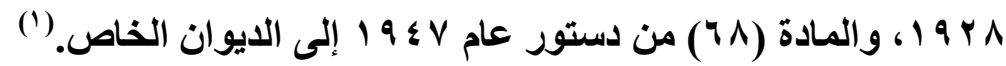

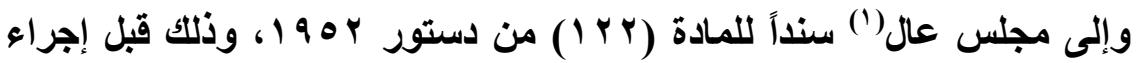

$$
\text { التعديلات الاستورية. }
$$

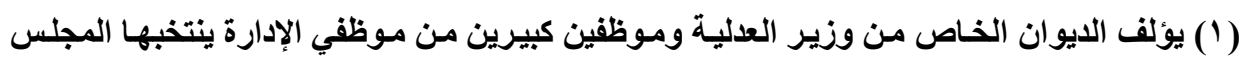

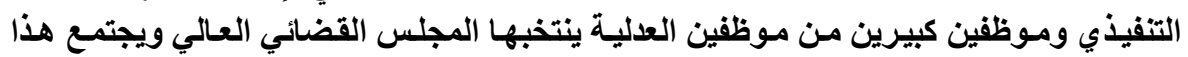

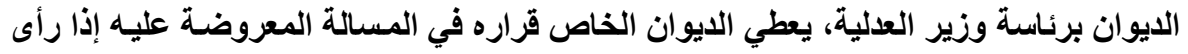

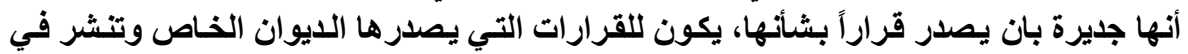

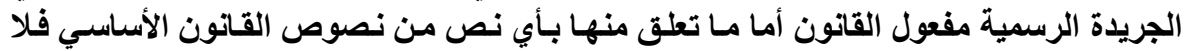

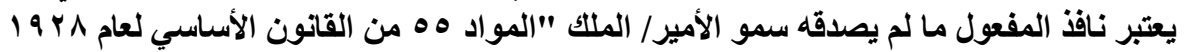

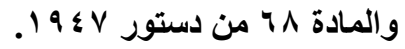


وقد بلغ عدد القرارات التي صدرت منذ عـام ( • ا9 إلى عـام Y I • ) إحدى

$$
\text { وخمسين قراراً. }
$$

ومما يجد التذكير أنه في حالة وجود مراكز قانونية اكتملت عناصرها واستقرت في ضوء ما صدر عن المجلس العالي، فلا يجوز ان تمس هذه المراكز، لمـا يشكله هذا المساس من عدوان على الحقوق التي ولاتها هذه المراكز وتجريداً لأصحابها منها بعد

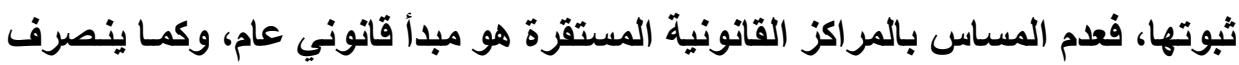
إلى المراكز القانونية التي اكتملت عناصر ها قبل صدور القرارات التفسيرية الصادرة عن المحكمة الدستورية ويطبق أيضاً على المراكز القانونية التي استقرت قبل صدئ صدور

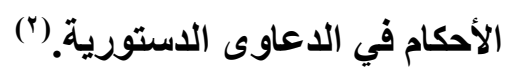

\section{الإطلب الثاني: بعد إنشاء المكمة الدستورية}

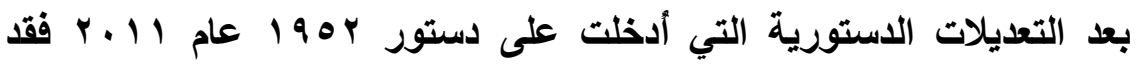

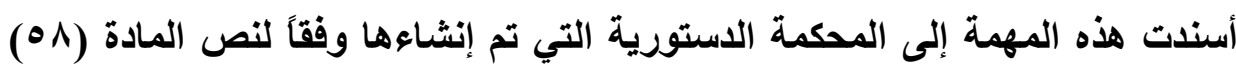

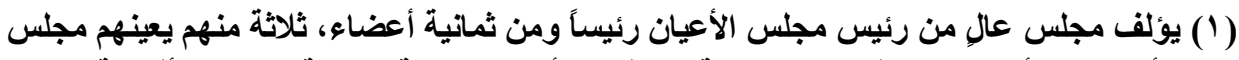

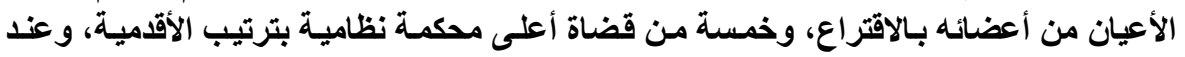

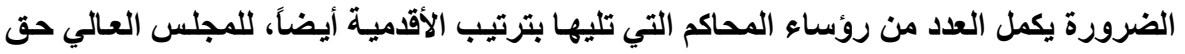

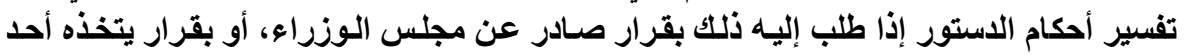

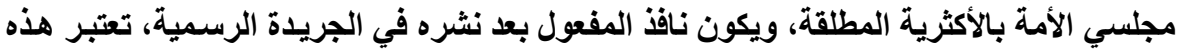

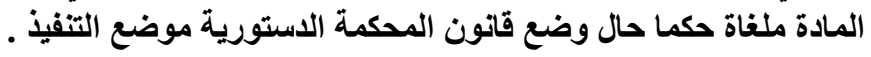

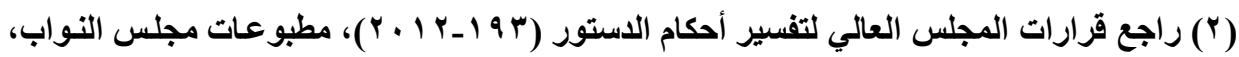

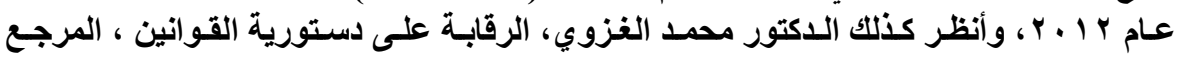

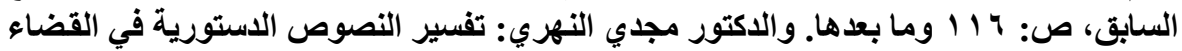

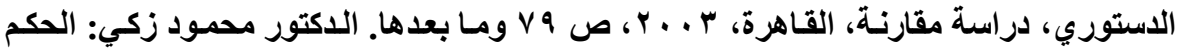

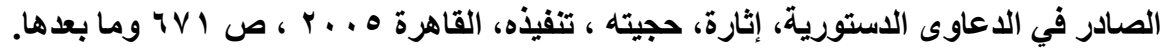


من الاستور والمادة الثالثة والرابعة من قانون المحكمة الاستورية ، على أن "تنشأ بقانون محكمة دستورية يكون مقرها في العاصمة وتعتبر هيئة قضائية مستقلة قائمة

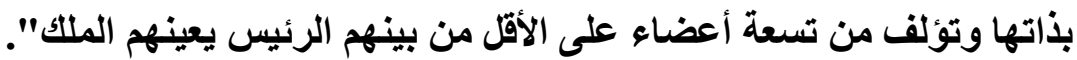

وإذا ما رجعنا إلى المادة (ه9) من الدستور التي تنص على اـ تختص المحكمة

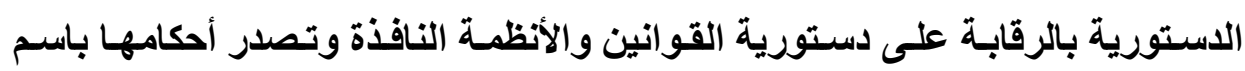
الملك، وتكون أحكامها نهائية وملزمة لجميع السلطات وللكافة، كما تكون أحكامها ناقذة

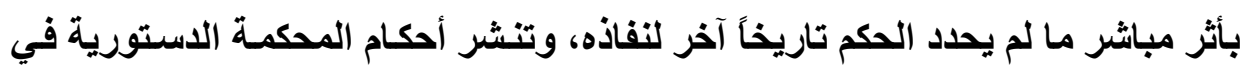
الجريدة الرسمية خلال خمسة عشر يوماً من تاريخ صدورها. r ـ للمحمة الاستورية حق تفسير نصوص الاستور إذا طلب إليها ذلك بقرار صادر عن مجلس الوزراء أو بقرار يتخذه أحد مجلسي الأمـة بالأغلبية ويكون قرارهـا نافذ المفعول بعد نثره في الجريدة الرسمية.

ونجد هنـا ان هذا النص هو مـا يطلث عليه (التفسير الملزم) وعند مراجعتـا

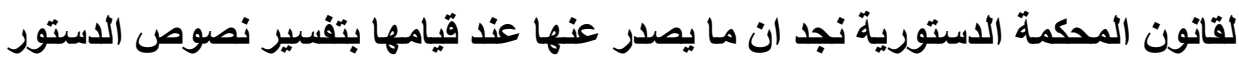

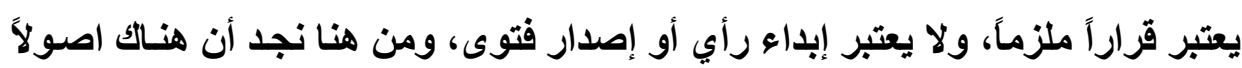
لطلب التفسير لابد من التقبا بها. كما أن النصوص السابقة وعلى خلاف المواد التي تنظم قضاء رقابة الدستورية

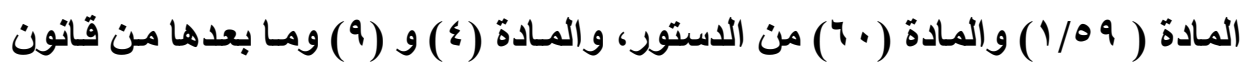
المحكمة لا تتضمن اي شرط لقبول طلب التفسير. لكن السؤال الذي يطرح نفسه هو ما الذي يشترط لقبول طلب التفسير وانعقاد الولاية للمحكمة الدستورية في هذا الخصوص؟. 


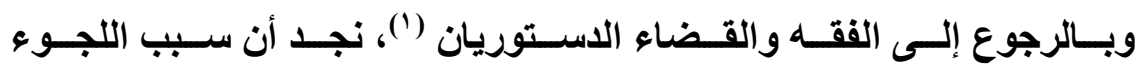

إلسى طلـب التفسير هـو أن يقـع خـلاف حـول نـص دسـتوري فيكـون تــلـل المحكمـة الاستورية بالتفسير لازمـاً رفعاً للتضارب في مفهوم النص، وتحديداً لمعنـاه القانوني

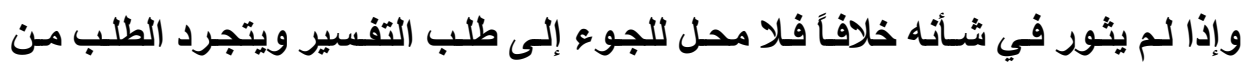
مقومات قبوله.

وبالنسبة للتفسير الذي يتسم بالطابع العملي والأكثر شيوعاً هو التفسير غير

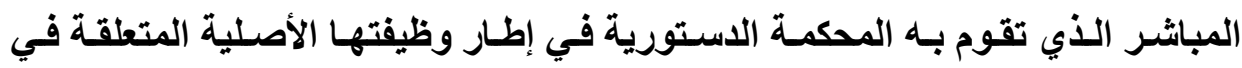
دستورية القوانين والأنظمة المرفوع أمرهـا أمامها. فيصدر الحكم بـه بمناسبة دعوى إسه

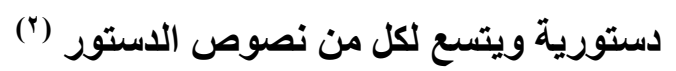

\section{( ) (1) راجع في هذا تفصيلاً}

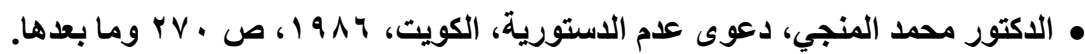

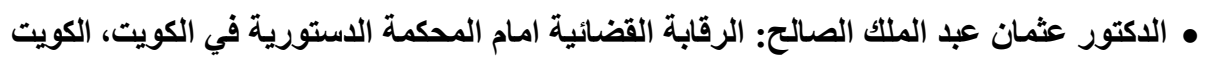

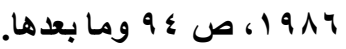

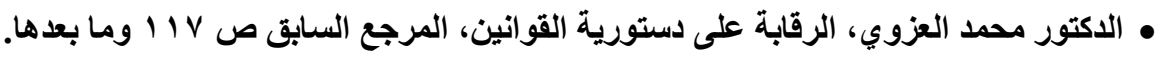

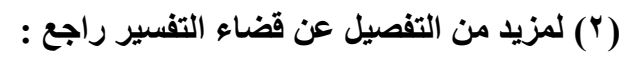

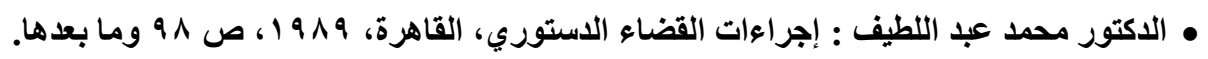

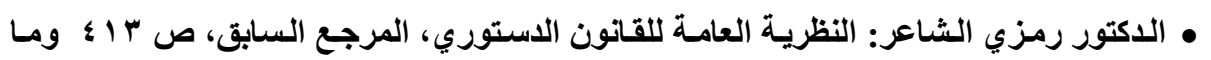
• الدكتور مجدي النهري: تفسير النصوص الدستورية في القضاء الدستوري، دراسـة مقارنة،

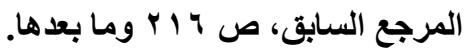

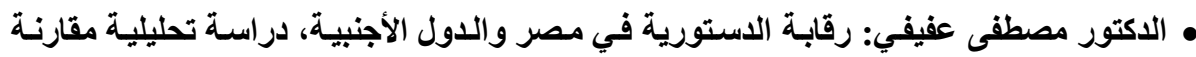

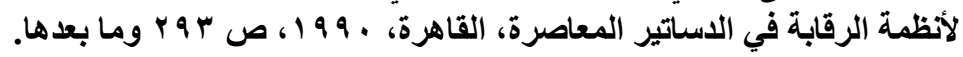

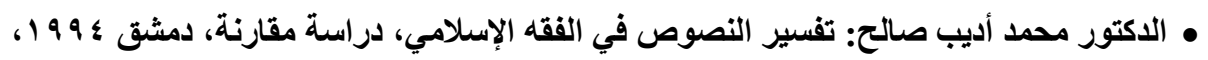

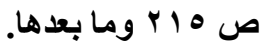


وبالنسبة للفقه الاستوري فهو يذهب إلى القول عن دور القاضي الدستوري في

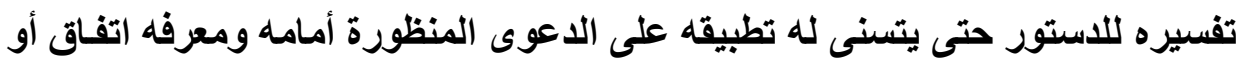

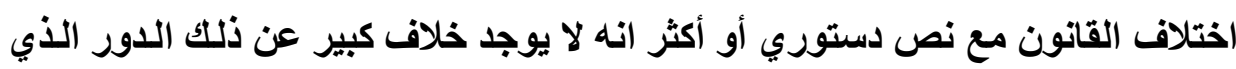

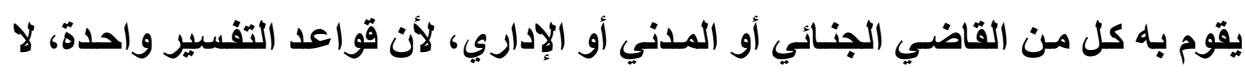

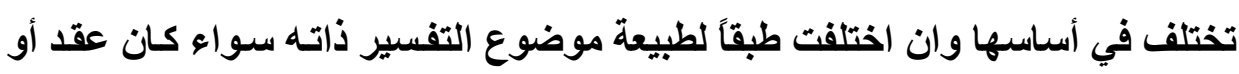
قانون أو دستور. (1) وأخيراً ومما تجدر الإثارة إليه لأهميته وهو أن المحكمة الدستورية، هي بصدد

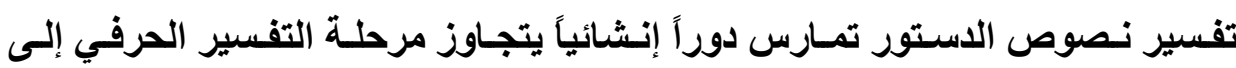

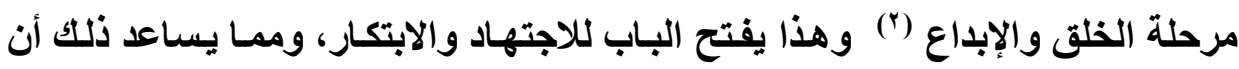

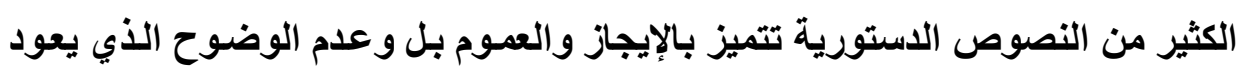

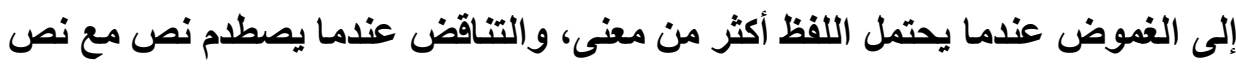

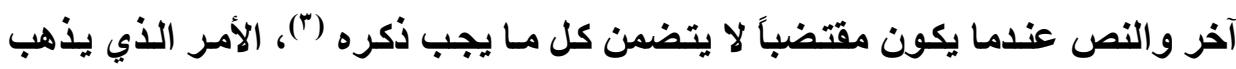

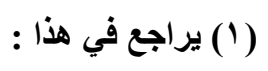

• الاكتور عصام سليمان، تفسير الاستور وأثره على المنظومة الاستورية، بث منشور في الكتاب

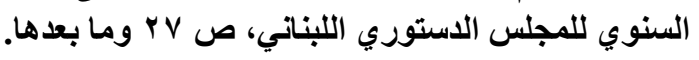

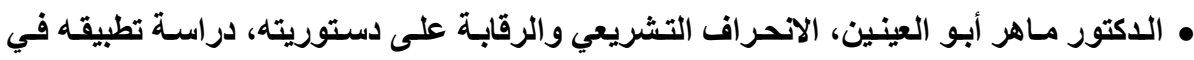

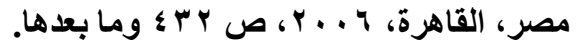

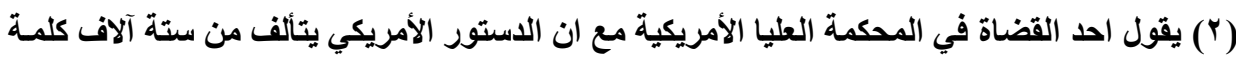

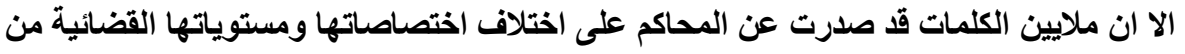

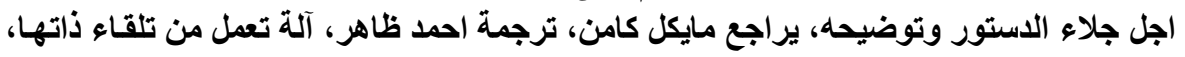

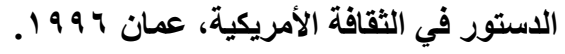

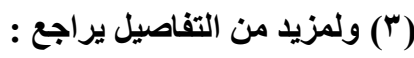
• الاكتور مجدي النهري : تفسير النصوص الدستورية في في القضاء الدستوري، المرجع السابق،

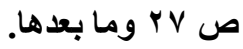
$=$ 


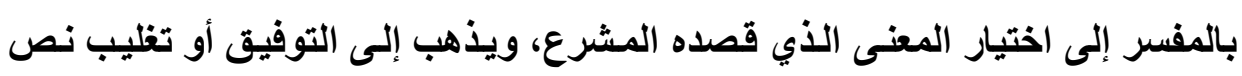

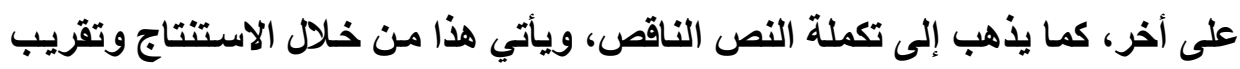

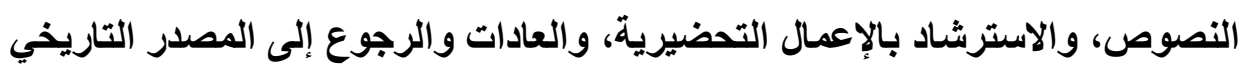
للتشريع. (')

• الدكتوران عبد الرزاق السنهوري وحشمت أبو سنتيت ، أصول القانون، المرجع السابق، ص

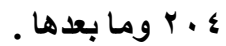
(1) يراجع تفصيلاً كل من الدكتوران عبد الرزاق السنهوري، وحشمت ابو ستين، أصول القـانون، المرجع السابق، ص ا بـ وما بعد ها. 


\section{المبحث الثاني \\ الأمكام والقرارات الصادرة عن المكمة الدستورية}

بداية واستناداً إلى المادة الرابعة من قانون المحكمة الاستورية رقم (0 1 ) لسنة

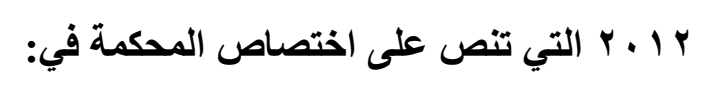

أ. الرقابة على دستورية القوانين والأنظمة النافذة.

$$
\text { ب. تفسير نصوص الدستور. }
$$

فقد أفردنا هذا المبحث لبعض الأحكام وقرارات التفسير (').

وسوف نتطرق لحكمين وقرارين تفسير على سبيل المثال لا الحصر وذلك في

$$
\text { مطلبين: }
$$

المطلب الأول: أمثلة هن الأمكام التي قضت بها المحكمة الدستورية

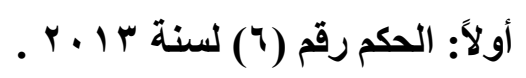

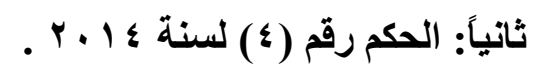

$$
\begin{aligned}
& \text { أولاً: الحكم رقم (1) لسنة rا.r. }
\end{aligned}
$$

يتلخص هذا الحكم بقيام مجلس النواب باعتباره أحد الجهات التي لها حق الطعن

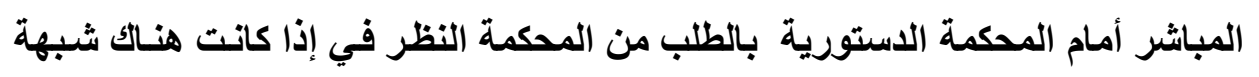

$$
\text { (1) لقد صدر حتى الآن عن المحكة (101) حكماً و (r 1) قراراً تفسيرياً. }
$$


دسـتورية تعتـري المـواد الثالثة والخامسسة والثامنـة والسـادسة والعشرين، والثالثة

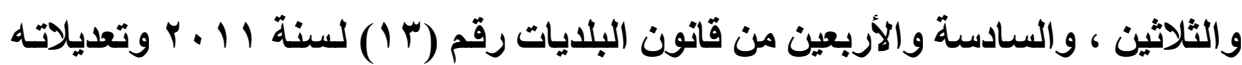
ودون إن تحدد النصوص الاسـتورية التـي تخالفهـا هذه المـواد الـواردة في القـانون

وبناء على هذا الطلب وبعد الدراسة والتدقيق، أكلات المحكمة بأغلبية أعضائها بأنها ليست جهة استشارية وإنما اختصاصها محدد بـالنظر بعدم دستورية القوانين والأنظمة النافذة وكذلك تفسير نصوص الاستور فقط، ولا يوجد اختصاص استشاري لـذه المحكمة.

واسـتناداً لمـا سـبق قـ قـام أغلبيـة أعضاء المحكمـة بـرد الـدعوى شـكلاً لعدم استكمال الدعوى شروط الطعن بهذا القانون.

وبالمقابل نجد أن رئيس المحكمة، وعضو المحكمة الدكتور محمد العزوي، قد

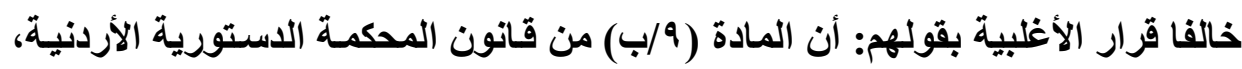
قد خلت من الإشارة إلى ضرورة تضمين النص القـاتوني الدستوري المدعي بمخالقته

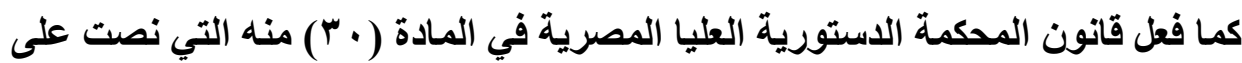
"أنه يجب أن يتضمن القرار الصادر بالإحالة إلى المحكمة الدستورية العليا أو صحيفة الاعوى المرفوعة إليها وفقاً لحكم المادة السابقة بيان النص التشريعي المطعون بعدم دستورية والنص الدستوري المدعي بمخالفته وأوجه المخالفة".

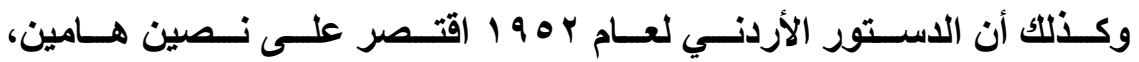

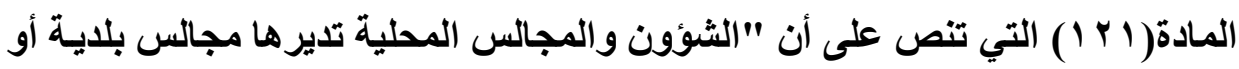

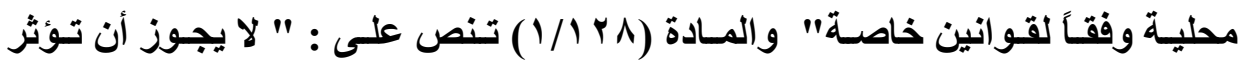
القوانين التي تصدر بموجب هذا الاستور لتنظيم الحقوق والحريـات على جوهر هذه الحقوق أو تمس أسساسياتها". 
ونحن نجد أن الرأي المخالف في هذه الدعوى هو الأقرب للصواب لأن المشرع

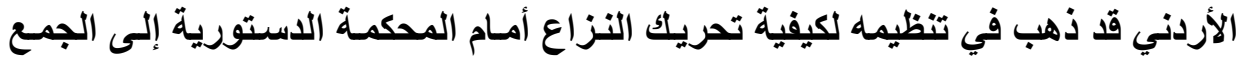
بين الدعوى الأصلية أو الطعن المباشر و الدفع الفرعي.

كمسا أن الاستور قد رسم ملامسح التفسير السليم للرقابـة الاستورية في هذا

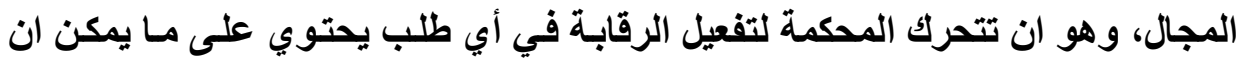
يقع المحكمة بحقيقة المسألة مثار الطلب دون لبس لذا كان يتوجب عليها قبول التول الطعن والنظر فيه موضوعاً.

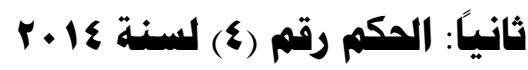

يتلخص هذا الحكم ان المستدعي سليم ساكت المعاني كان قد طعن أمسام محكمة

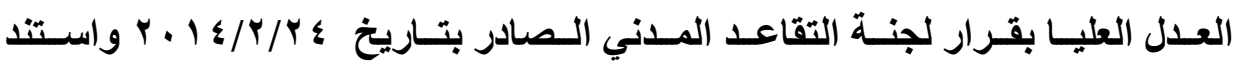

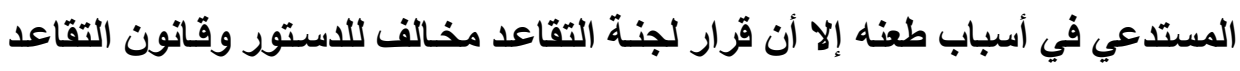

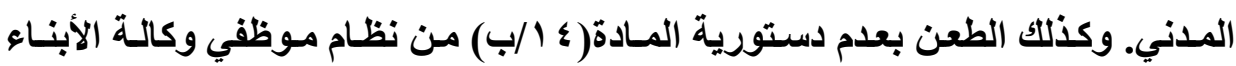

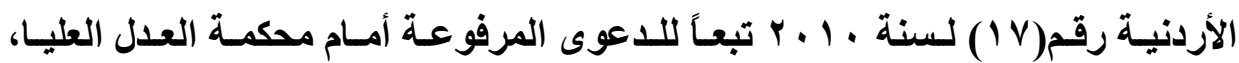
وتتلذص دعواه أن هذا النص غير دستوري ويخـالف أحكام المسادة (†) من الاستور الأردني.

وبعد دراسـة هذا الطعن مـن قبل المحكمة الدستورية ، فقد قضت المحكمـة

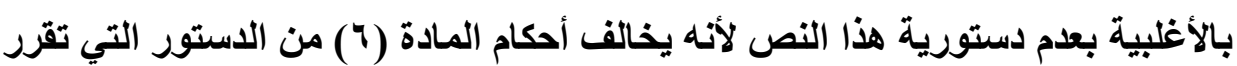
المساواة أمام القانون عندما يتماثلون في المراكز القانونية. و هناك رأي مخالف لرأي الأغلبية ويؤسس هذه المخالفة على أن نظام موظفي

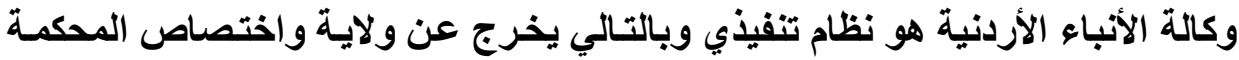

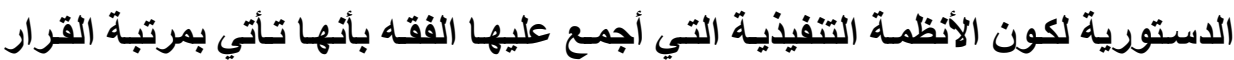


الإداري الذي يختص بالنظر في مشروعيتها وهو القضاء الإداري سنداً لقانون محكمة

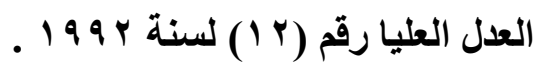
ونحن نؤيد مـا ذهبت إليه الأغلبية حيث نجد أن المسادة (9 ه) ومـا بعدها من

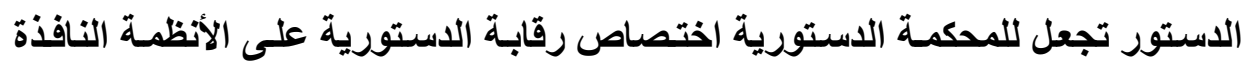
دون تقييد أو تخصيص.

وكذلك خلال تحليلنـا للنص القانوني في قانون المحكمة الدستورية نجـ أنسه

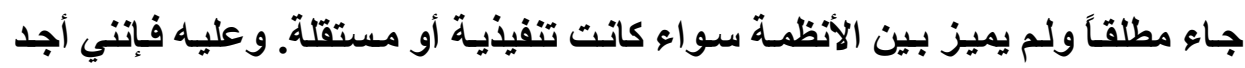

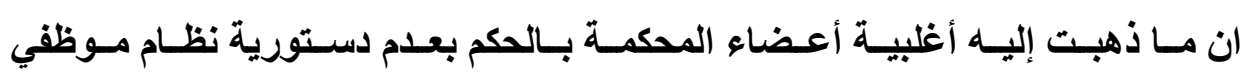

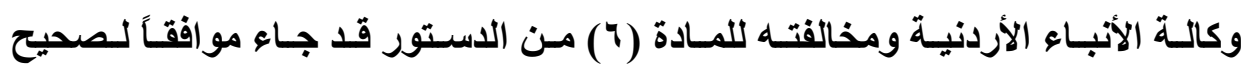

\section{الملب الثاني : أهثلة هن قرارات التفسير التي صدرت عن المكمة الدستورية

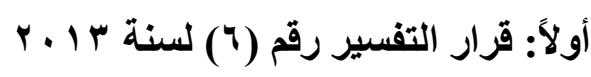

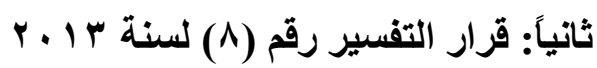

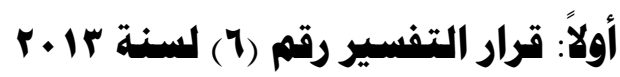

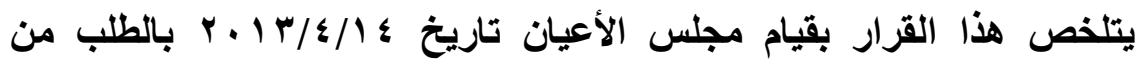

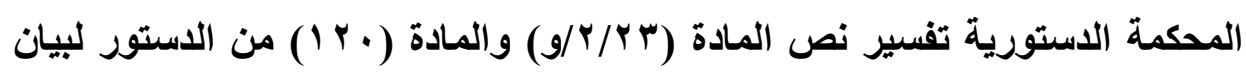

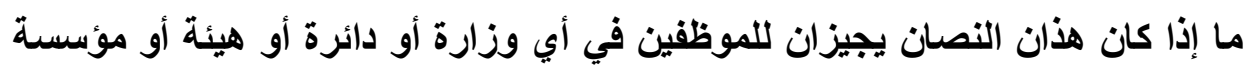


حكومية ان ينشئوا نقابة خاصة لهم وهم موظفون تابعون لنظام الخدمة الددنية، ولا يوجد لوظائفه مثيل في القطاع الخاص خارج إطار الحكومة. وكانت مناسبة طلب التفسير أثناء شروع مجلس الأعيان بمناقثة قانون الأئمة

$$
\text { و العاملين في الأوقاف الإسلامية لعام ب ب ـ ب. }
$$

وقد أسست المحكمة الاستورية تفسيرها لهذين النصين بالاستناد ابتداءاً إلى نص المادة (14) من الاستور الأردني التي أجازت تثكيل النقابات بشرط أن تكون غايتها مشروعة. ومتو افقة مع أحكام الاستور وعدم مخالفة أحكامه وكذلك يجب أن يتم التمان تنظيم أحكام هذه النقابة بقانون.

كما أن المادة (rT) من الدستور قد عالجت المسائل المتعلقة بالعمل وحقوق العمال بالنسبة لجميع المواطنين الأردنيين من خلال ضمانات تمثلت بتثريعات خاصة تنظم المبادئ الواردة في هذه المادة.

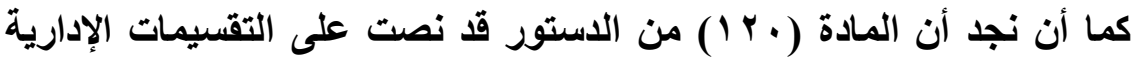
وتثكيلات الإدارة العامة بشكل عام وكافة الأحكام المتعلقة بالموظفين العموميين. وقد قامت المحكمة باستعراض كافة النصوص والمواثيق الدولية التي تجيز انثاء النقابات المهنية بما يتوافق أحكام القانون. وقد خلصت المحكمة أنه يجب قراعة أنداءة كافة النصوص القانونية مع بعضها البعض.

ونرى أن هذه القاعدة لا يختلف عليها اثنان. حيث أن النصوص يجب أن تقرأ كوحدة واحدة لأن كل نص يكمل الآخر إذا كان يتطلق بذات الحكم القانوني. وذهبت المحكمة إلى جواز إنشاء النقابات المهنية للموظفين العموميين بشرط أن يتم إصداره بقانون. ويتو افق مع أحكام الدستور الذي كفل لهم هذا الحق. 
وبرأينا أن المحكمة قد أصابت عند تفسيرها لهذه النصوص الاستورية حيث أنها جاعت مطلقة والقاعدة الأصلية في التفسير أن المطلق يجري على إطلاقها ما لم الم

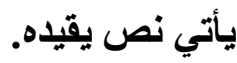

وكذلك جاعت النصوص المطلوب تفسيرها مطلقة حيث يفهم منها انه يجوز

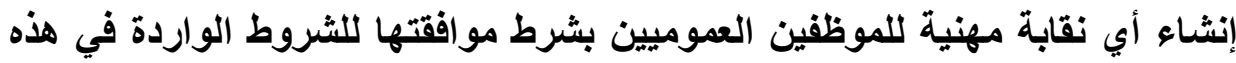

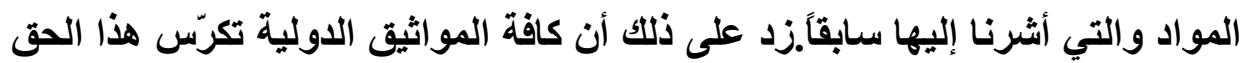
الذي يعد من اهم الحقوق الإنسانية لكونه يعطي الموظف العام من خلال نقابته المطالبة بحقوقه بثكل مؤسسي موضوعي وجماعي وليس فردي.

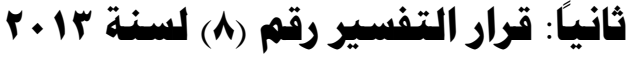

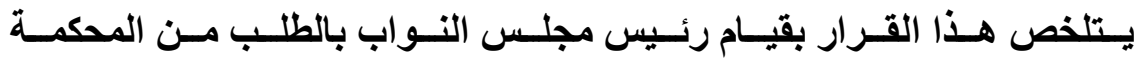

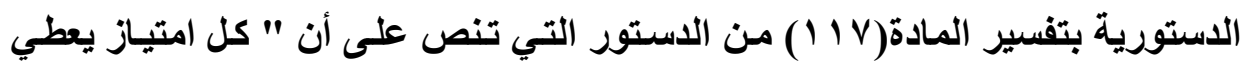

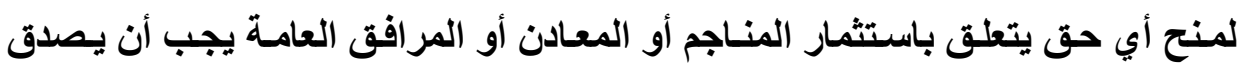

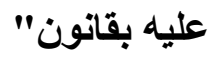

وكاتت مناسبة طلب التفسير هو أن عقد الامتياز الخـاص بعقار مطار الملكة

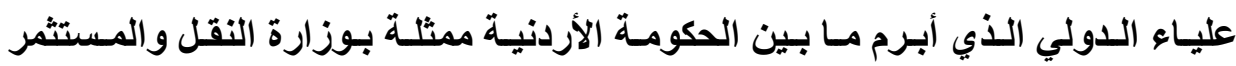
لمدة(ه r) سنة، والذي تمت المصادقة على هذا الامتياز بموجب قانون الطيران المداني

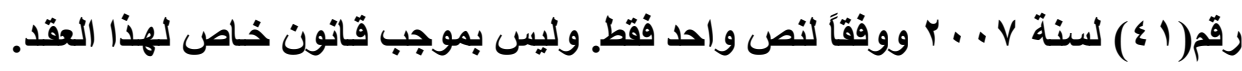

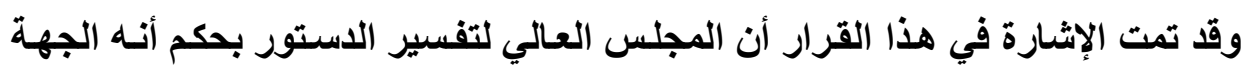

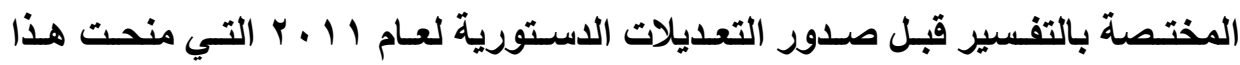
الاختصاص للمحكمة الاستورية.

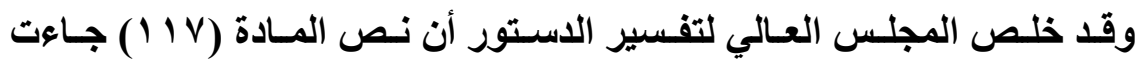

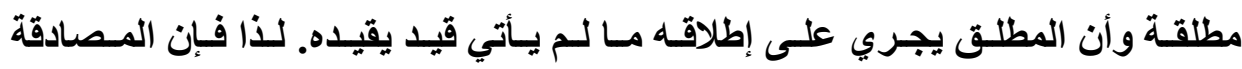


على هذا العقد تصح حتى لو كان وفقاً لنص مادة يتيمة في قانون الطيران المدني دون

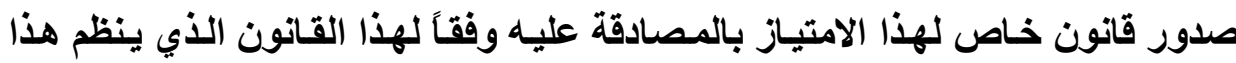

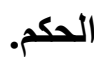

ونحن نعتق أن المحكمة الاستورية قد أصابت عذدما لم تتطرق إلى تفسير هذا

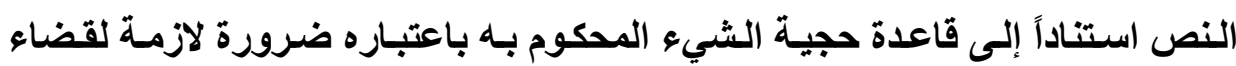
المشروعية والرقابة الاستورية.

كمسا نـرى أن قـرار التفسير الـصادر عـن المجلس العسالي لتفسير الاستـور

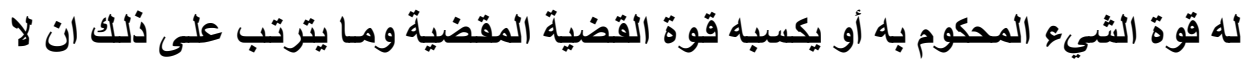

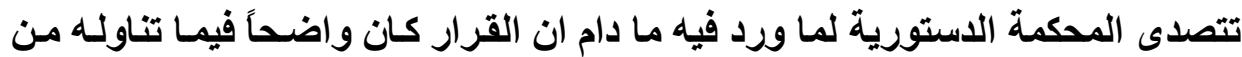

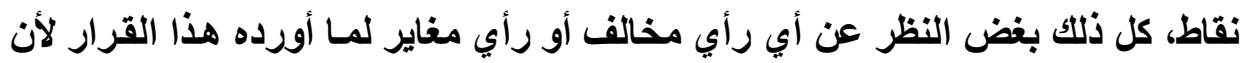

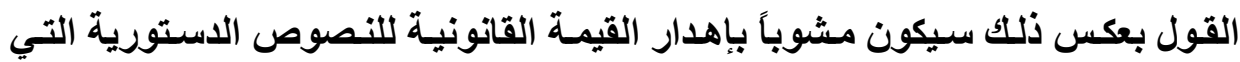

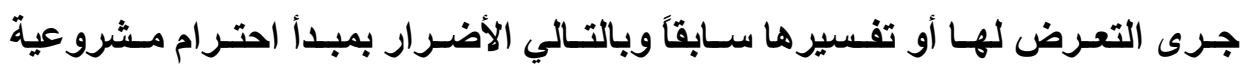
النصوص، وبخاصة أن الموضوع بتعلق بطلب من طلبات التفسير وليس من طلبات الإلغاء. 


\section{الخاتهة}

لقد بينـا في هذا البحث موضـوعاً في غايـة الأهميـة والمتمثل باختصاصات المحكمة الدستورية الأردنية. وذلكت من خلال فصلين، تتاولنا في الفصل الأول أسـاليب الرقابة على دستورية القو انين و الأنظمة النافذه، وذلك في مبحثين: تطرقنا في المبحث الأول إلى طريقة الطعن المباشر بعدم الاستورية من خلال الدعوى الأصلية، والذي يتم من قبل مجلس الأعيان ومجلس النواب ومجلس الولئ الوزاري، وأفردنا المبحث الثاني لطريقة الدفع بعلم دستورية القوانين والأنظمة والتي بحثناهـا

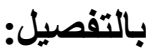
أما الفصل الثاني فقد حدادا فيه صلاحية المحكمة بتفسير النصوص الاستورية

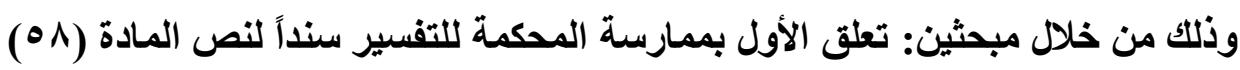
من الاستور، و المادة الثالثة والرابعة من قانون المحكمة الاستورية أما المبحث الثاني

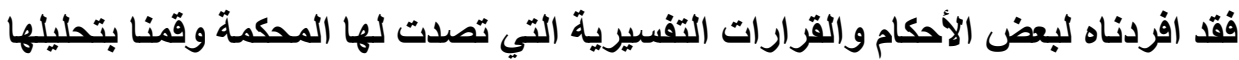

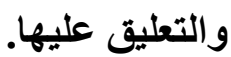
وخلاصة القول أن النظام القانوني الأردني قد أكتمل تكوينه. حيث أصبح الأردن

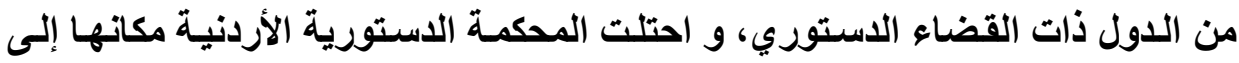
جانب كل من القضاء العادي و القضاء الإداري والقضاء الثرعي. وفي نهاية هذا البحث توصلنا إلى التوصيات التالية ، التي نأمل من المشرع الأردني أن يؤخذ بها: أولاً: نتمنى على المشرع الأردنـي أن يحقق الضمانات الكافية للقضاء وذلكك بــمم استقلاله العضوي و الوظيفي من الناحيتين النظرية والعملية. 


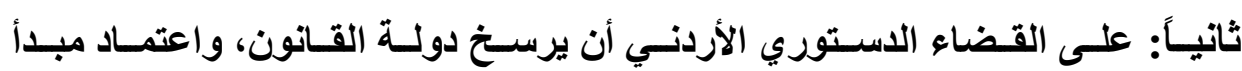
المشروعية لا مبدأ الملائمة في إصدار أحكامه وقراراته.

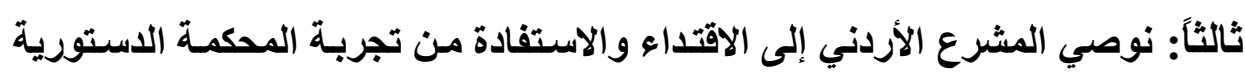

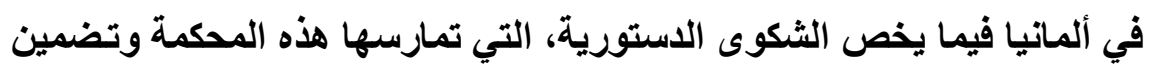

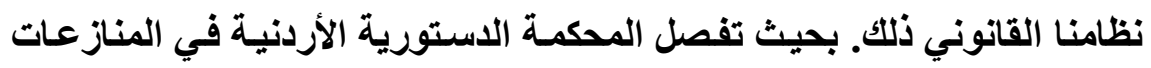

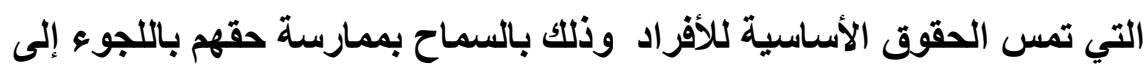
المحكمة بواسطة الثكوى الاستورية. رابعاً: كمـا نوصـي المشرع الأردنـي أن يعطي الحـق للأحزاب والنقابـات ومنظمسات

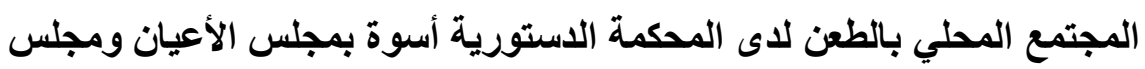

$$
\text { النواب ومجلس الوزراء. }
$$

خامساً: نوصي بفتح الباب للاجتهاد والابتكار لأن الكثير من النصوص الاستورية

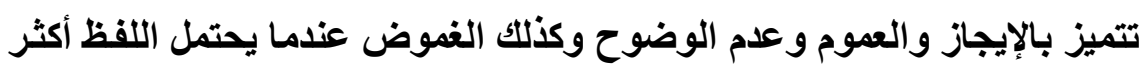
من معنى أسوة بالقضاء الاستوري المصري.

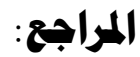 \\ أولاً: الكتبب:}

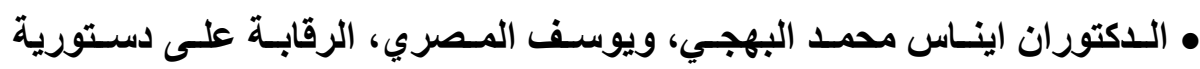

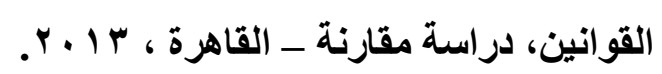

• الدكتور ثروت بـوي، القانون الاستوري وتظور الأنظمـة الاستورية ، القـاهرة $.19 \times 1$

• الــكتور حسن عبــ الحميد، قاعـدة السـابقة القـضائية فـي الـنظم القانونيـة

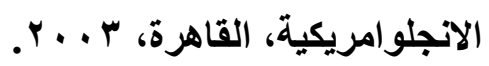


• الاكتور ديتر هوميج: مقدمة عن تاريخ ومهام المحكمة الدستورية الألمانية، من منشورات وزارة العدل حول دور ومهام المحاكم الاستورية المنعقدة خلال الفترة (V-7)

• الدكتور رمزي الثاعر : النظرية العامـة للقانون الاستوري ـالطبعة الخامسة ـ

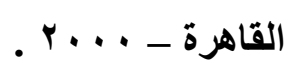

• الــكتور رمـزي السشاعر، رقابـة دستورية القـوانين- دراسـة مقارنـة، القـاهرة

.$r \ldots \varepsilon$

• الدكتور سعد عصفور: مقدمة في القانون الاستوري، القاهرة ؛019 1.

• الدكتور عبد الحكيم عبد الجليل، المعارضة في الفكر السياسي الإسلامي والوضعي

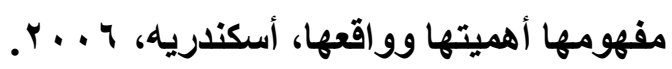

• الاكتور عبد العزيز سالمان - رقابة دستورية القوانين ، القاهرة، ه99 19. • الاكتوران عبد الرازق السنهوري ، وحشمت ابو ستيت ، أصول القانون، القاهرة. • الدكتور عبد المنعم محفوظ - علاقة الفرد بالسلطة، الحريات العامـة وضمانات

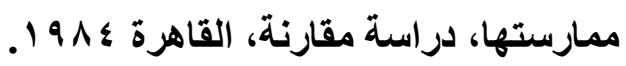
• الدكتور عثمان عبد الملك الصالح: الرقابة القضائية امسام المحكمة الدستورية في

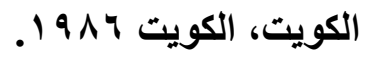

• الاكتور علي الباز، الرقابة على دستورية القو انين في مصر مع المقارنة بالأنظمة

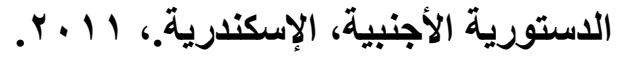

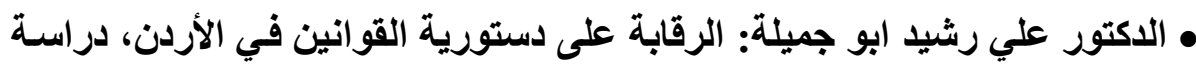

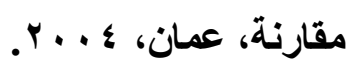


• الاكتور ماهر أبو العينين، الانحراف التشريعي والرقابة على دستوريته، دراسة

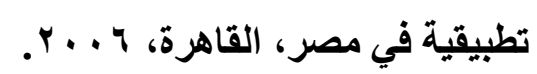

• مايكل كامن، ترجمة احمد ظاهر، آلّة تعمل من تلقاء ذاتها، الدستور في الثقافة

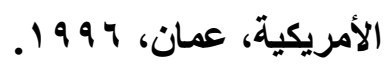

• الدكتور مجدي النهري: تفسير النصوص الاستورية في القضاء الاستوري،

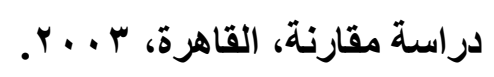

• الاكتور محمد أديب صالح: تفسير النصوص في الفقه الإسلامي، دراسـة مقارنة،

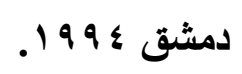

• الدكتور محمد العزوي، نظرات حول المبادئ العامة عن الدولة، الدساتير والقانون

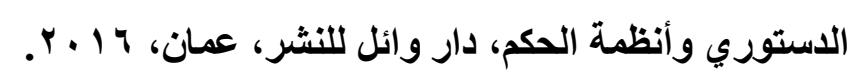

• الدكتور محمد الغزوي : الوجيز في الرقابة على دستورية القوانين، دراسة في كل

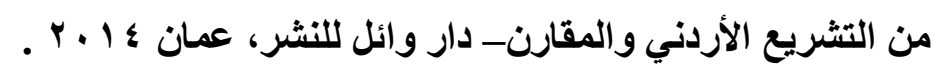

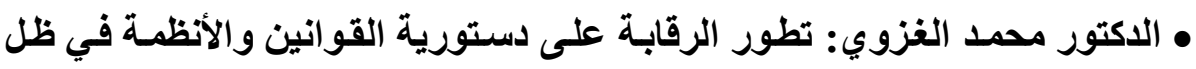

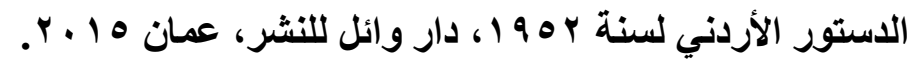
• الدكتور محمد الغزوي: خواطر حول قانون إنشاء المحكمة الدستورية الأردنية

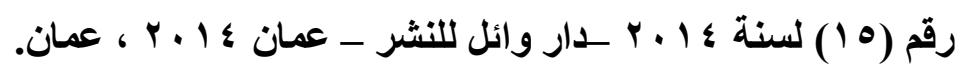
• الاكتور محمد المنجي، دعوى عدم الدستورية، الكويت، 1919.

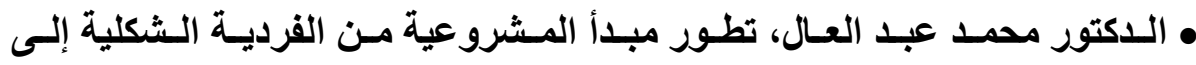

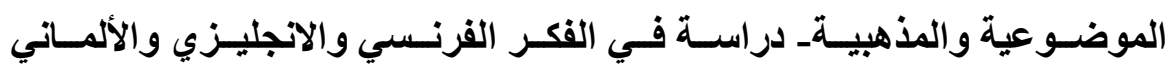

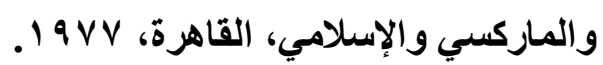




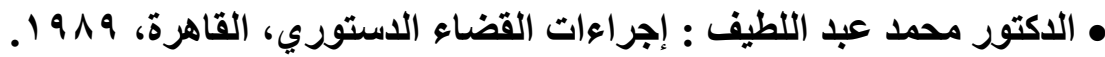
• الدكتور محمد عصفور، سيادة القانون، الصراع بين القانون والسلطة في الشرق

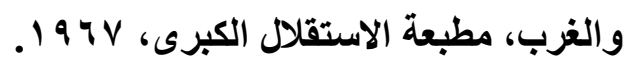

• الدكتور محمد فؤاد عبد الباسط : ولايـة المحكمة الاستورية العليا في المسائل

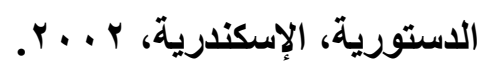

• الدكتور محمود زكي: الحكم الصادر في الدعاوى الدستورية، إثـارة، حجيته ،

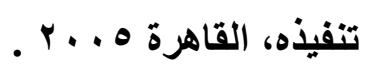

• الدكتور مصطقى عفيفي: رقابـة الدستورية في مصر والدول الأجنبيـة، دراسـة

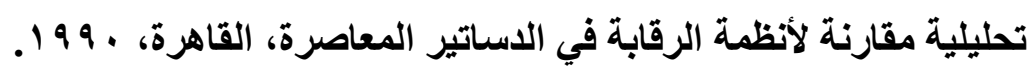

• الدكتور نواف كنعان، مبادئ القانون الاستوري والنظام الاستوري الأردني، وفقاً للتعديلات الاستورية لعام 11 ـ r. مكتبة الجامعة، الشارقة.

• الدكتور هشام عبد القتاح، رقابـة دستورية القوانين، دراسـة مقارنـة بين أمريكا ومصر، القاهرة

\section{ثانيًا: الرسائل الجاهمية والأبماث:}

• الاكتور احمد كمال أبو المجد: الرقابة على دستورية القوانين في الولايات المتحدة

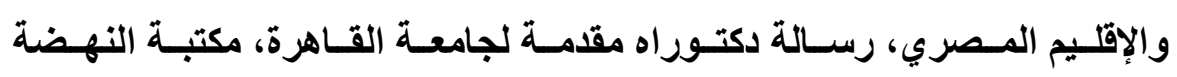

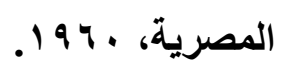

• الدكتور عصام سليمان، تفسير الدستور وأثره على المنظومـة الاستورية، بحث منشور في الكتاب السنوي للمجلس الاستوري اللبناني. 


$$
\begin{aligned}
& \text { ثالثًا: القوانين والأنظمهة: }
\end{aligned}
$$

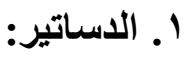

$$
\begin{aligned}
& \text { • القانون الأساسي لعام ^ } 9 \text { 1 1. } \\
& \text { • الاستور الأردني لعام V \9 1. } \\
& \text { • الاستور الأردني لعام r } 9 \text { ه وتعديلاته. } \\
& \text { • الاستور الألماني لعام } 9 \text { \ } 9 \text { وتعديلاته. }
\end{aligned}
$$

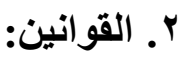

• قانون المحكمة الدستورية الأردنية رقم 1 لسنة ب ا ـ ب.

• قانون محكمة العدل العليا رقم r ا لسنة ra 99 ـ.

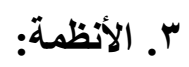

• النظام الداخلي لمجلس الأعيان لسنة ؛ 1 • ؟ .

• النظام الداخلي لمجلس النواب لسنة ؟ ا • ؟ .

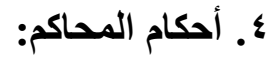

• أحكام المحكمة الدستورية العليا المصرية. • أحكام المحكمة الاستورية الأردنية. • أحكام محكمة العدل العليا الأردنية. 